Portland State University

PDXScholar

\title{
The People's Soul Engineers: A Study of Secondary Teachers in the People's Republic of China
}

\author{
Nancy Benson \\ Portland State University
}

Follow this and additional works at: https://pdxscholar.library.pdx.edu/open_access_etds Let us know how access to this document benefits you.

\section{Recommended Citation}

Benson, Nancy, "The People's Soul Engineers: A Study of Secondary Teachers in the People's Republic of China" (1988). Dissertations and Theses. Paper 1237.

https://doi.org/10.15760/etd.1236

This Dissertation is brought to you for free and open access. It has been accepted for inclusion in Dissertations and Theses by an authorized administrator of PDXScholar. Please contact us if we can make this document more accessible: pdxscholar@pdx.edu. 


\section{INFORMATION TO USERS}

The most advanced technology has been used to photograph and reproduce this manuscript from the microfilm master. UMI films the text directly from the original or copy submitted. Thus, some thesis and dissertation copies are in typewriter face, while others may be from any type of computer printer.

The quality of this reproduction is dependent upon the quality of the copy submitted. Broken or indistinct print, colored or poor quality illustrations and photographs, print bleedthrough, substandard margins, and improper alignment can adversely affect reproduction.

In the unlikely event that the author did not send UMI a complete manuscript and there are missing pages, these will be noted. Also, if unauthorized copyright material had to be removed, a note will indicate the deletion.

Oversize materials (e.g., maps, drawings, charts) are reproduced by sectioning the original, beginning at the upper left-hand corner and continuing from left to right in equal sections with small overlaps. Each original is also photographed in one exposure and is included in reduced form at the back of the book. These are also available as one exposure on a standard $35 \mathrm{~mm}$ slide or as a 17" $\times 23^{\prime \prime}$ black and white photographic print for an additional charge.

Photographs included in the original manuscript have been reproduced xerographically in this copy. Higher quality $6 " \times$ " 9 " black and white photographic prints are available for any photographs or illustrations appearing in this copy for an additional charge. Contact UMI directly to order.

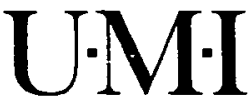

University Microfilms International

A Bell \& Howell Information Company

300 North Zeeb Road, Ann Arbor, MI 48106-1346 USA

313/761-4700 800/521-0600 
Order Number 8914726

The people's soul engineers: A study of secondary teachers in the People's Republic of China

\section{Benson, Nancy, Ed.D.}

Portland State University, 1988

Copyright (C)1988 by Benson, Nancy. All rights reserved.

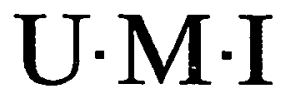

300 N. Zeeb Rd.

Ann Arbor, MII 48106 
-

$=$ 
THE PEOPLE'S SOUL ENGINEERS:

A STUDY OF SECONDARY TEACHERS IN THE PEOPLE'S REPUBLIC OF CHINA

By

NANCY BENSON

A dissertation submitted in partial fulfillment of the requirements for the degree of

\author{
DOCTOR OF EDUCATION \\ in \\ EDUCATIONAL LEADERSHIP
}

Portland State University

1988 
TO THE OFFICE OF GRADUATE STUDIES:

The members of the Committee approve the dissertation of Nancy Benson presented July 8, 1988.
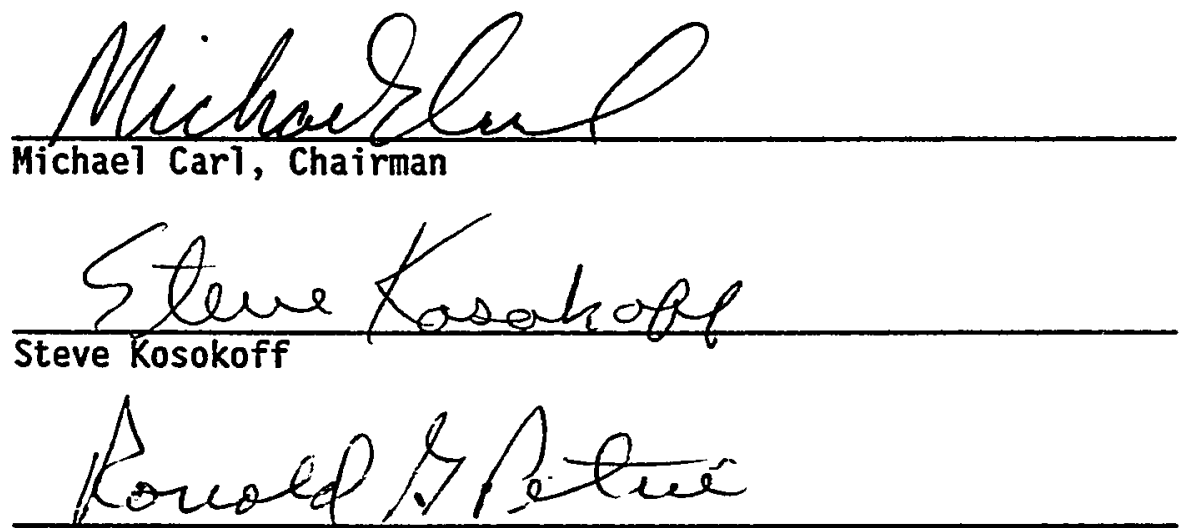

Ronald G. Petrie
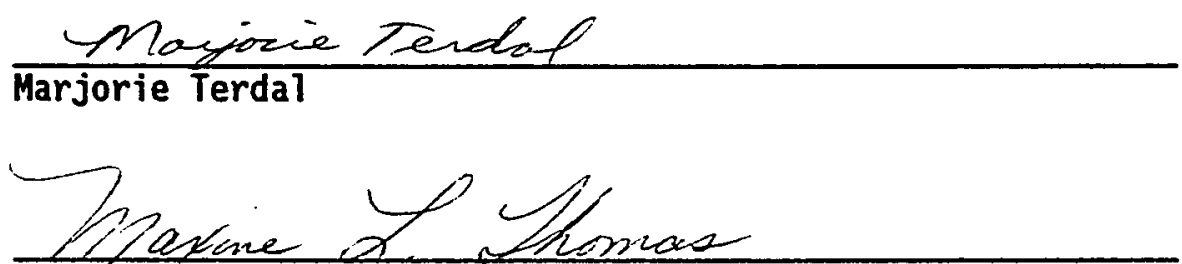

Maxine Thomas

APPROVED:

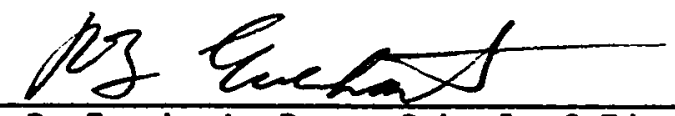

Robert B. Everhart, Dean, School of Education

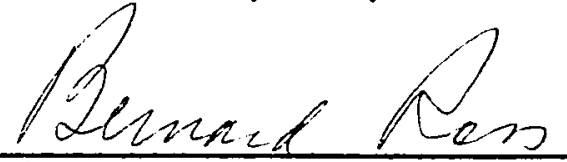

Bernard Ross, Vice Provost for Graduate Studies 
AN ABSTRACT OF THE DISSERTATION OF Nancy Benson for the Doctor of Education in Educational Leadership presented July 8, 1988.

Title: The People's Soul Engineers: A Study of Secondary Teachers in the People's Republic of China.

APPROVED BY MEMBERS OF THE DISSERTATION COMMITTEE:
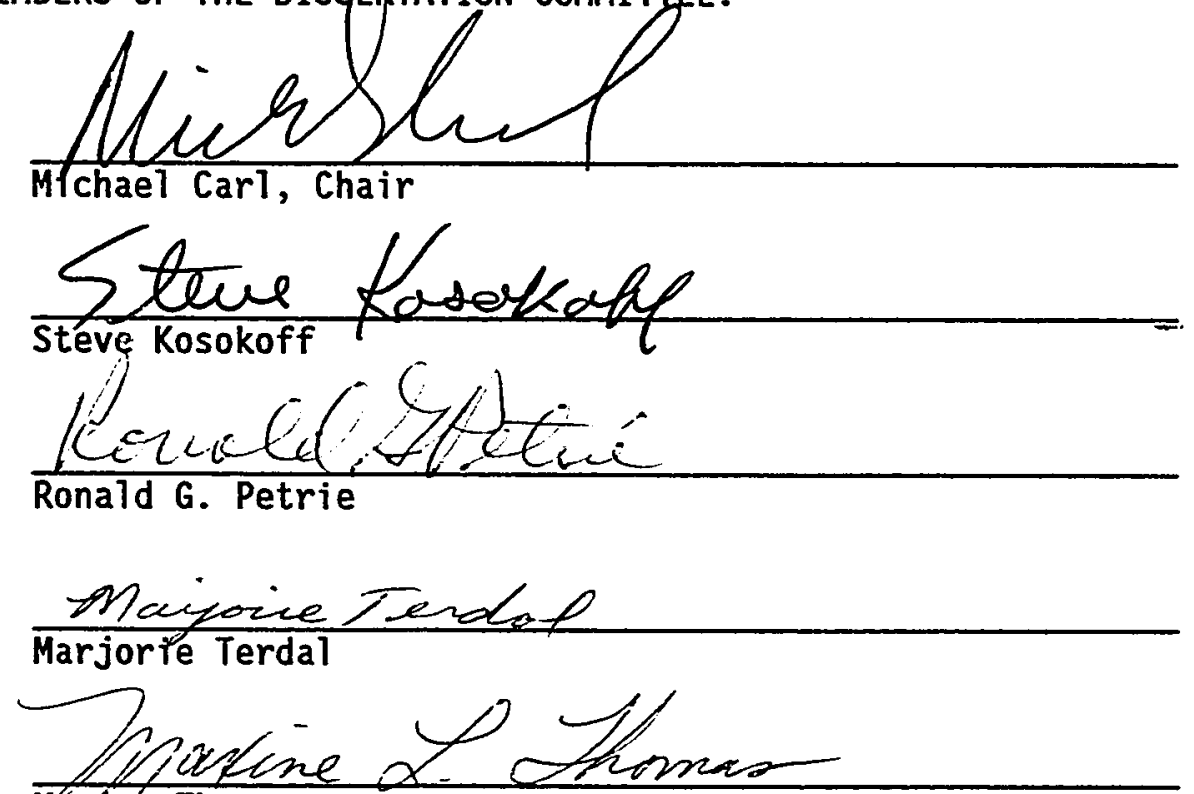

Maxine Thomas

This study was designed to explore the beliefs of teachers in the People's Republic in China regarding education policy, work conditions in the schools, teacher education, student discipline, curriculum, and the teaching profession. Subjects were 60 secondary teachers in the Beijing area, from both "keypoint" and "ordinary" schools. The teachers completed a 60-item questionnaire, designed to assess multiple educational belief dimensions. 
The results revealed that, as a group, teachers perceived themselves as having poor social status, inadequate pay, limiting work conditions, and a lack of opportunities for advancement. Teachers also reported a high degree of stress and health problems. There were distinct patterns of responses reflecting beliefs that students should be given more freedom to speak their minds and that students' ability to think is more important than memorizing facts. Teachers expressed a high interest in helping students learn and working for the good of society. Regarding educational policy, teachers believed that the government does not adequately support education nor teacher preparation.

This pattern of results varied by demographic factors. For example, male teachers reported stronger perceptions that their families lack pride in them as teachers. Teachers without degrees felt more strongly that resources at their schools were less adequate. 01der, more experienced teachers reported a stronger belief in permissive parenting as the major cause of behavior problems in the schools, and agreed that parents should be responsible for their child's moral education. Younger teachers expressed the most dissatisfaction with their pay and also felt that younger teachers are more capable than older teachers.

A cluster analysis revealed statistical separation of teachers into three groups. The first group of teachers was younger, less experienced, and better educated. They expressed the most dissatisfaction with being teachers and felt the lowest social status. However, they also believed that they made a difference in the lives of their students. The second teacher group reported teaching as 
more challenging and stressful, advocated the need for strong discipline, and felt they made little difference in their students' lives. These teachers were more experienced, older, and less educated. Thie teachers in the third group who shared common demographic characteristics with group two, were the most positive about their social status, pay, and commitment to teaching. They reported more support and resources than teachers in the other two groups, and felt they make a difference in their students' lives.

Results of this study extend previous findings regarding the beliefs of teachers in the People's Republic of China. Through the use of multivariate techniques, three types of teachers emerged. The implications of these findings are discussed both with regard to government interest in reforming educational policy and directions for future research. 


\section{ACKNOWLEDGEMENTS}

I would like to express my gratitude to several people who helped make this research possible: First, to my sister, Linda Benson, whose adventurous spirit took her to Asia to study and teach, and who led me to my first interest in China, my deepest appreciation for her continuous support. Secondly, to Christine Sproul and Jack Van de Water of the International Study Programs of the Oregon State System of Higher Education, I extend appreciation for the confidence they expressed when sending me to China in 1986. My experiences there led to this study. Next, my thanks goes to Richard Sonnen, Head of the Special Studies Department, School of Education, at Portland State University, who facilitated my stay in China and who has given me continuous encouragement and support. I thank Rosalind Wang of the Education Library at Portland State for her assistance, as a translator, resource person, amd friend. To Li Wei, formerly of Beijing Teachers College, a very special thanks for his translation work, his invaluable perspectives, and his friendship. I would also like to thank Mike Carl, chair of my dissertation committee and my advisor, for his steadfast support and confidence. To Steve Kosokoff and Marge Terdal I extend my heart-felt appreciation for their constructive suggestions to earlier versions of this dissertation. I am especially grateful to my husband, Tom Moran, for his unfailing support, advice, and caring, without which this study would not have been possible. And finally, a very special thanks to those Beijing teachers who generously gave of their time to participate in this project. 
TABLE OF CONTENTS

PAGE

ACKNOWLEDGEMENTS .......................... . . . .

LIST OF TABLES ......................... vi

CHAPTER

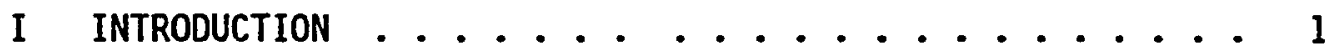

A Global View of Education in the Eighties ..... 3

Education in Developing Countries ........ 6

Teachers' Views of Their Role in Educational Development 9

II REVIEW OF THE LITERATURE (A HISTORY OF EDUCATION

AND THE TEACHING PROFESSION IN CHINA) ....... 12

Education in Ancient China ......... 12

The Period of Foreign Influence and the New Republic . 15

Mao and the Communist Influence ......... 19

Education under the Kuomintang (National) Government . 21

Education After Liberation ......... . 24

The Effect of the Cultural Revolution on Teachers

and Education ............... 31

Post-Mao Education in China .......... 33

The Status of the Teaching Profession in Modern China. 39

Teacher Education in Modern China . . . . . . . 42

Qualities of an Ideal Teacher in Modern China .... 51

School Curriculum and Teaching Methodology ..... 52

Teacher-Student Relationships .......... 58 
Educational Research in China .......... 61 Hypotheses Regarding Chinese Teachers and Their Beliefs 64 III METHOD ........................... 66 Subjects ................. 66 Questionnaire............. 68 Procedure ................ 69 IV RESULTS .................. 71

Demographic Characteristics of the Study Sample ... . 71 Description of Questionnaire Responses . . . . . 73 Demographic Differences by Teacher Beliefs . . . . 74 A Belief Typology Based on Cluster Analysis . . . . . 78 V DISCUSSION ...................... 84

Summary . . . . . . . . . . . . . 85

Conclusions ..................... 93

Recommendations ............... 99 REFERENCES ............................ 102

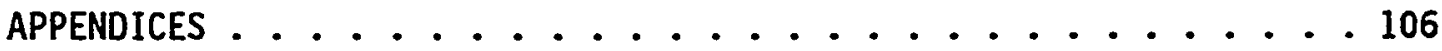

A. Teacher Questionnaire (English) ........... 107

B. Teacher Questionnaire (Chinese) ........... 111

C. Letter to Participants (English) . . . . . . . . 115

D. Letter to Participants (Chinese) . . . . . . . . 116

E. Glossary .................... 117 


\section{LIST OF TABLES}

$\begin{array}{ll}\text { TABLE PAGE } & \text { PA }\end{array}$

I Percentage of Qualified Teachers, 1965-1980 . . . . . . 47

II Analysis of Variance Variables Which Maximize Discrimination Among Cluster Groups . . . . . . . . 80

III Teacher Beliefs Based on Cluster Analysis ........ 83 


\section{CHAPTER I}

\section{INTRODUCTION}

The purpose of this study is to investigate the perceptions and beliefs of teachers in the People's Republic of China, so that a current and accurate picture of the teaching profession there might emerge. To date very little research has been conducted which concerns itself with understanding China's teachers and the social context of teaching. However, there is growing concern within China for the profession of teaching and the state of education, despite the low priority given them by the government. This is evidenced by the number of recent articles in the Chinese press (Zhang, 1986 and Li Xing, 1987 and 1988) and in foreign publications (Johnson, 1986), as well as a recently reported pay raise for teachers (Guo, 1988). Chinese authorities have attempted to raise the status of the teaching profession by such means as declaring an annual "National Teachers' Day" and by bestowing titles upon teachers. One such example, "the People's Soul Engineers," attempts to assign a professional and inspirational title to teaching (Lo, 1984). The intuition which guides this research is based on the notion that despite very different cultures, ideological traditions, and institutional structures, many countries, both developed and developing, share similar concerns in the area of education. Many of these concerns will be explored in this paper, but particularly those pertaining to the teaching profession itself. Without such an understanding of teachers, 
the way in which they see their work, and the impact of educational changes upon them, attempts to improve teaching will be "hit and miss" (Broadfoot and Osborn, 1987).

In order to understand the current education situation in China, it is important to examine the history of schooling and the teaching profession. The effects of Marxist ideology on education have, of course, been significant. But China's size, in both geography and population, has been the cause of many difficulties in the provision of educational opportunities. Two factors contributing to the poor quality of schooling have been 1) very limited government spending for education, in relation to other areas, and 2) maltreatment or distrust of "intellectuals," i.e. teachers and other educated classes. The result of these national policies has been low status for the teaching profession, causing many young people to avoid teaching careers and causing some experienced, trained teachers to leave.

To summarize, this paper will first discuss a current global view of education and the teaching profession in order to establish the common nature of the issues. China is, of course, only one of a number of developing count ies which are having a particularly challenging task in delivering educi ional services and preparing and retaining teachers. An over: lew of these issues is provided, along with a discussion as to $h_{i}$ teachers have seen their occupational roles, especially teacher in developing countries where research in education has been 1 inited.

A brief overview of the 2,000 year-old Confucian education 
tradition, interrupted by the intrusion of foreign education systems, will furnish perspective for a discussion of education in modern China. The status of teachers, an historically honored profession, fell dramatically after nationalization of the schools. This paper will describe the political processes and decisions most influential in forming the education system as it exists in China today. But most importantly, the paper hopes to provide an understanding of teachers in China, the way in which they see their work and the impact upon them of contemporary changes in education.

\section{A GLOBAL VIEW OF EDUCATION IN THE EIGHTIES}

Education is in crisis in many countries, both "developed" and "developing," i.e. third world, and significant reforms have been proposed and are being implemented (Coombs, 1985). In a few, including the U.S., the teaching profession is perceived as a major component of reform. In much of the world, however, there is more concern for a sufficient number of teachers and for teachers with appropriate training (Dove, 1986). Teachers are at the center of the educational process, yet their views on education and their profession are often overlooked. In addition, many countries seem to have an implicit belief that significantly upgrading the teaching profession may be too difficult (Altbach, 1987).

Reforming teacher education and allowing teachers to participate in educational decision-making are two areas receiving attention in many countries in the 1980s. The Japanese, for instance, are moving toward a more "humanistic" school system with less emphasis on 
memorization and growing concern over the stressful examination system. Teachers play an important role in Japan's new educational thinking (Coombs, 1985). India has announced a national reform plan which includes vocational emphasis in secondary and higher education. India's teachers, however, are not a focus of this effort (Coombs, 1985). The Soviet Union is also infusing vocational content into the curriculum and making education more relevant to Soviet technological development. Teacher education is part of Russia's overall reform (Coombs, 1985). The U.S. education reform movement is, generally, pressing for a more rigorous, academic curriculum with less vocational emphasis at the high school level. Teacher education and the teaching profession are to play key roles in the reform, as outlined in several proposals (Holmes Group, 1986, and the National Commission on Excellence in Education, 1983).

Preceding this international concern for the current situation of schooling, was the rising wave, in many developing countries, of protests against repression and of popular demands for participation and greater equality. Students and teachers were frequently leading forces in protest movements in Pakistan, Chile, Nicaragua, El Salvador, Poland, Ethiopia, and Iran (Coombs, 1985). China recently joined the ranks of nations experiencing public demonstrations led by students (Mann, 1987).

Schools and higher education institutions have generally been in the middle of such socioeconomic and political disruptions and have often been charged with being part of the problem or the cause. Teachers have come in for their share of criticism (Altbach, 1987, Good1ad, 1984, and others) and many countries have realized that without 
good teachers all other innovations are doomed to failure (A7tbach, 1987). Concerns about the funding of education are worldwide, applicable to developed as well as developing countries. The process of educational reform at any level and in any country is a difficult one. Even in highly centralized countries such as China and the Soviet Union, educational reforms are difficult to implement. Typically, reforms are precipitated by a perceived crisis and proposed by authorities in power. Those at the bottom of the education system, i.e. the teachers, are charged with implementing the changes, often without adequate resources. Because public school teachers stand at the door of the school, they are naturaliy seen as agents of government school policy, whether in opening wide the door to all children or restricting access and opportunity (Dove, 1986).

Demographic factors are another set of significant forces affecting education. The post World War II population explosion resulted in expanded education systems over the next two decades. Developing countries found it impossible to maintain their existing school participation, let alone expand it, due to the rapidly growing school-age population (Coombs, 1985). Industrialized countries found the baby boom ending in the mid sixties, with subsequent reductions in enroliment by the mid-seventies.

This demographic turnaround removed pressure for educational expansion in industrialized countries. Instead the focus has changed from quantitative expansion to qualitative improvement, due in part to a changed attitude on the part of the public resulting from growing educational costs, overstrained tax structures, and mounting criticism 
of the schools (Coombs, 1985). Meanwhile, in the developing countries, there is still a race between population and education growth, and no change forseen.

\section{EDUCATION IN DEVELOPING COUNTRIES}

In the 1950s, Western economists proposed economic growth theories, which had worked well in postwar Western Europe and Japan, to be applied to developing countries. It was assumed that large capital infusions and modern technology transfer to the newly independent agrarian nations of Asia and Africa, as well as to the nations of Latin America, would enable these countries to modernize and develop at a fast pace. The developing countries, however, lacked the educated labor force, the industrial know-how, and the administrative infrastructure necessary for economic growth. In order to increase the supply of educated manpower, modern educational and training models which had worked in the industrialized world, were funded. Increased education budgets were encouraged and supported by such organizations as the World Bank and UNESCO. The majority of developing countries made impressive progress in raising their Gross National Products, and in increasing their educational enrollments. But by the 1970s the disturbing facts of what was actualiy happening in the "real worid" of development came to 1 ight.

In 1973 Robert McNamara, president of the World Bank, stunned the economic and development communities by asserting that 800 million people, almost half of the developing world, were living in extreme 
poverty (Coombs, 1985). And the numbers were growing. New surveys by other agencies also revealed huge proportions of landless families, spreading unemployment, poor health, contaminated water supply, nonexistant sanitation, inadequate nutrition, and high infant mortality. Intensifying all these problems was a high rate of rural population growth, despite heavy migration to the cities.

Despite glowing impressions of progress in education enrollments found in UNESCO Statistical Yearbooks, the true picture of developing nations' rural schools began to emerge (UNESCO, 1980). Among the problems were lack of schools, high dropout and absentee rates, deteriorating buildings, few textbooks or other basic supplies, and poorly qualified teachers. In many rural areas, less than 10 percent of the children completed primary school and perhaps only 10 percent of these went on to secondary schools. In addition, the curriculum was often geared to the urban, academically oriented student and did not fit the needs of rural children. While additional schooling seemed to be contributing to increased productivity, at the same time the absolute number of illiterates in the Third World increased (World Bank, 1980).

The urban education situation was certainly better than that of the countryside, especially for the children of the middle and upper classes. Participation rates were higher and schools, particularly primary schools, were better equipped and staffed. The curriculum was generally more appropriate and the opportunities to attend secondary school were much greater. In 1960 there were 144 million pupils in developing country (excluding the People's Republic of China and Korea) 
primary and secondary schools, and in 1976, 335 million (Carnoy, 1982).

For all the shortcomings, education in developing countries has improved greatly in the last two decades. The gains have, however, been exceedingly lopsided with the comparatively well-off becoming more so, and the masses of poor people becoming poorer (Carnoy, 1982 and Coombs, 1985). A reexamination of the nature of development, along with a broader view of education, has emerged in the seventies and eighties. There has been increased emphasis on rural development, including education, jobs, housing, nutrition, clothing, and health care. of special interest has been improving the status of women and children.

Revised policies in "basic education" for developing countries seem to be emphasizing primary school for children and appropriate nonformal education for out-of-school youth and adults, with less emphasis on secondary and higher education. Also stressed is the quality of education and the relevance of the curriculum, along with more efficiency in administration (Coombs, 1985).

It has been said that one of the principal functions of schooling in the Third World is to substitute for political rights and for increased material consumption (Carnoy, 1982). Increased schooling helps compensate for present injustices by persuading the poor that there is hope for the future -- hope that their children will do better by going to school. Producing a literate population, however, could be a source of demands for radical change. Others suggest that teachers are agents of a capitalist ruling class which uses the schools as instruments of domination, creating class divisions through hierarchical school organization and stratified curricula (Dove, 1986). 
TEACHERS' VIEWS OF THEIR ROLE IN EDUCATIONAL DEVELOPMENT

How teachers view their place in society and their role in curriculum and the educational process have been the subject of study in but a few countries, most notably those in Western Europe and North America. Books such as Teacher (Ashton-Warner, 1963), Up the Down Staircase (Kaufman, 1964), and 36 Children (Kohl, 1967), were among the first widely read books about teaching, by teachers, in the U.S. These were followed by works such as School Teacher: A Sociological Study (Lortie, 1975), Fifteen Thousand Hours (Rutter, 1979), a British study of the effects of schoors on students, and A Place Called School (Goodlad, 1984), a U.S. study of schooling which includes the results of surveys and interviews with over 1,000 teachers. How teachers in developing countries view themselves and their occupational role and status has not been a topic of much investigation, however.

Society is amiguous towards teachers. It expects them to be agents of both tradition and change (Dove, 1986). Since people's occupational roles tend to emerge from society's expectation of them and their own image of themselves, this ambiguity may be one of the causes for little interest in exploring teachers' views, even when educational reform is underway.

The United States is currently debating many educational issues related to the teaching profession. Perhaps no other nation is devoting as much time to studyirg the issues of curriculum, teaching/learning strategies, teacher qualifications, and teacher preparation. However, seldom do we hear directly from school teachers. Several authors 
(Travers, 1987, and others) have noted that teachers are generally represented as numbers or clusters of behaviors or parts of $\mathrm{classroom}$ ecology. For example, in the most recent Handbook of Research in Ieaching (Whittrock, 1986), there are 1,037 pages and 35 chapters by 58 scholars from five countries, but only a single chapter that reviews attempts to understand teaching from the teacher's perspective.

Not surprisingly, the U.S. academic culture seldom looks overseas for an international perspective of teachers, even though concern about the teaching profession is worldwide (Altbach, 1987). It is the goal of this paper to look at the experience of another country, the People's Republic of China (referred to hereafter as China), in the hope that it might add a useful perspective. At first glance, the notion of studying China's teaching profession might seem to offer little of interest to U.S. academicians. China has recently emerged from semi-feudalism, with about 80 percent of the over one billion people living in rural areas. It is estimated that the illiteracy rate is about 25 percent (Hooper, 1985). A compulsory education act was passed in 1986 and it is estimated that about90 percent of eligible children begin primary school, with about 40 percent dropping out between grades one and five, often to go to work (Arnove, 1984). China's rural teachers often do not have a senior high education, nor teacher preparation (Lo, 1984, Bastid, 1984, and others). Those teachers who do have training often have no desire to be teachers, having been assigned to the profession by the government (Zhang, 1986, Johnson, 1986 and others). Schools, especially in rural areas, are often unsafe, unfurnished, dirty, dark, and without libraries. Parents often must pay 
tuition which, while minimal, can prevent some students from attending school (Brown, 1986, Cleverley, 1986, and others).

Lipset (1967) advises:

To understand... American education, or any other institution, it is necessary to know how it differs from the comparable institutions in other countries. Only when one knows what is unique on a comparative scale can one begin to ask significant questions about causal relationships within a country (p. 348).

By examining such issues as the status of the teaching profession in Chinese society, the working condition of teachers there, and the beliefs of some who are teachers in China, it is hoped that insight may be gained into the teaching profession in general. A study of China's teacher education programs, the public school curriculum, and the examination system may lead to increased understanding of some U.S. educators' concerns about various aspects of current reform proposals in this country. Most importantly, this paper hopes to provide a glimpse into the world of school teachers in modern China. 


\section{CHAPTER II}

\section{A REVIEW OF THE HISTORY OF EDUCATION AND \\ THE TEACHING PROFESSION IN CHINA}

In 1949, China's new leaders inherited an educational sytem that was fragmented, dysfunctional, inequitable, and unsuited to modernization. Furthermore, there remained the vestiges of the 2,000 year-old Confucian educational tradition which persists to this day (Hawkins, 1982).

\section{EDUCATION IN ANCIENT CHINA}

Chinese culture has been dominated by the works of Confucius (551-479 BC), whose ethical teachings became the main basis of both family and political relations from the Han dynasty until the last imperial dynasty, the Qing, which fell in the Revolution of 1911. Confucius, the most respected teacher in the history of China, had established a reputation as a good teacher by age twenty because of his good moral standing and profound knowledge. His ability to teach students according to their needs and abilities was to become a standard for subsequent generations of teachers. Mencius, another great teacher in Chinese history, also saw the importance of using different methods in approaching different students (Lo, 1984).

Confucian thought, an ethical code which established a set of hierarchical relationships to establish order in society, was a system 
of bonds similar to those in most traditional agrarian societies. To the Chinese, young people had to respect the authority of their elders and families needed to honor their forebears. Fathers and husbands held sway over the women of the family. On the national level citizens were required to pay homage to officials of the state, especially the emperor. The scholar-gentry elite of traditional China propagated that system through education, steeping themselves in the Confucian classics and maintaining their prestigious positions in society. Teaching and learning were generally accomplished through individual master-disciple relations. The illiterate majority learned of the Confucian precepts through oral traditions.

During the Han Dynasty (206 BC-24 AD), schools were established by the central government, as well as local governments, and an Imperial College was established. Sons of noblemen and high officials were educated in these central-administration schools and children from some landlord and merchant families were able to enroll in family or clan schools (a teacher invited to the home or lessons given in a teacher's home). Boys were taught to read and write characters at ages six and seven, and then spent the next decade memorizing the Chinese classics in preparation for the imperial examinations which were passed by only one or two out of every 100 students attempting them (Cleverley, 1985). Girls from the nobility were taught in the home, from about age seven, the skills of listening, conversation, and obeying. They were also instructed in skills related to food selection, music, and weaving, before their marriages at about age 15 (Cleverley, 1985). Some 
daughters of nobility were also taught reading and writing, as these were useful in arranging political marriages across families and clans, but there was debate over whether girls could be educated. Popular sayings at the time included, "a woman's lack of ability is her virtue," and "a woman without ability is normal" (Cleverley, 1985).

During the Sui and Tang dynasties (581-907 AD) schools specializing in calligraphy, mathematics, law, and medicine were formed at the local and central levels, but only for the wealthy. During this period the civil service examination system had a great impact on education, as the feudal rulers selected government officials according to their knowledge of the Confucian classics. On the one hand the examination system strengthened central autocracy and provided a means for a small number of intellectuals from the landlord class to enter official positions. On the other hand, it "degraded education and made it an appendage to the examination systun" (China Handbook, 1983). The high status of teaching was outlined by Han Yu (768-824) in his famous essay "The Teacher," where he described the aim of teaching not as the recitation of texts but as teaching knowledge and professional skills (Cleverley, 1985). During this era the highest grade of teacher did well through salary, free accomodation, gifts, etc., but the common teacher had a standard of living similar to that of a clerk or master workman and had to take on extra work in order to provide basic necessities (Cleverley, 1985).

It was every teacher's hope that his class would contain a gifted child. Artistic creativity was highly valued, as were talents in 
seeing, hearing, and remembering, and manual and mechanical skills.

During the Ming Dynasty (1368-1644 AD) military schools were established. Schools for young children taught reading and writing and high schools or academies taught the Confucian classics. Schools were general1y run by individuals, but by the Qing Dynasty (1644-1911) academies became governmental establishments (China Handbook, 1983). The poor could seldom attend school and a saying developed: "The rich never teach school and the poor never attend one" (Cleverley, 1985).

THE PERIOD OF FOREIGN INFLUENCE AND THE NEW REPUBLIC

During the late 1700 s and early 1800s, British, Americans, and others established missionary schools in the coastal areas of China, forming a colonial education system. In 1840, after China's defeat in the first Opium Wars, the number of these schools increased enormously, spread into the interior regions, and grew into an independent education system, primary through university, including schools for girls, all directly controlled by foreign powers. A growing number of wealthy families sent their young men and women to Europe, the U.S., and Japan (after the 1850s) to study, the latter being a particularly convenient location (Spence, 1981). Others were chosen, sponsored, and sent by provincial government authorities. Following China's defeat in the Sino-Japanese War (1884-1895), the Japanese system of education became an influential model in China.

The period of crisis surrounding the Taiping Rebellion (1851-1864) brought increasing western incursion and severe dislocation 
to China's political and economic order (Cowen and McLean, 1984). Four groups were particularly influential: 1) maritime/customs officers; 2) traders; 3) botonists; and 4) missionaries (Morton, 1980). The subject of missionary work and religious propaganda has become controversial, but there were a number of positive factors in the coming of churches to China. Missionary schools and universities made a notable contribution to Chinese education (Spence, 1981, Morton, 1980, and others). Schools for girls were first established by churches, as were public hospitals, training for doctors and nurses, orphanages, institutions for the blind and the mentally i11, engineering and agricultural schools (Morton, 1980). Missionaries were responsible for compiling the first Chinese-English dictionary and the first use of colloquial written language (Morton, 1980). They also established night schools for ordinary workers.

By the late nineteenth century, many of China's feudal warlords and bureaucrats established "Westernized" schools for training of translators, interpretors, and compradors. These schools taught foreign languages and "Western" arts (military and industrial technology), in addition to the Confucian classics. Also at this time, many Chinese reformists advocated such changes as the abolition of the imperial examination system, the establishment of new schools which would include the natural sciences and foreign languages, and schools for girls. The Qing government began to implement some of these educational reforms. In 1905 imperial examinations were abolished and marked the beginning of a "semi-feudal, semi-colonial, educational system" replacing the feudal system (China Handbook, 1983). 
Following the 1911 revolution, the "loyalty to the emperor" aim of education ceased, as well as exclusive schools for children of noblemen. Required courses in Confucian classics were abolished and applied science was stressed under Sun Yat-sen, provisional president of the Republic of China, and Cai Yuanpei, the first minister of education. Girls had more opportunities to obtain an education, though some revolutionary government leaders were not in favor of women's education (Spence, 1981). There was a growing movement to adopt a simplified written language that would represent the speech of the common people and therefore promote literacy. The number of educated teachers, men and women, grew, though only one in five teachers was female (Cleverley, 1985). Schooling for the five major ethnic groups of China (Han, Manchu, Mongolian, Tibetan, and Moslem) was promised, as well as more classes for the deaf and blind. However, republican plans for schooling were set back when Yuan Shikai attempted to take leadership in 1912 .

Several warlords committed themselves to modern schooling, founding primary schools and special schools for training engineers and teachers. Yan Xishan who controlled Shanxi Province from 1911 to 1949 built some 26,000 schools and had 80 percent of school age children in class by 1922, including 50 percent of eligible girls (Cleverley, 1985). He recruited teachers from poorer families and trained them at the People's Normal School. He was influenced by Dewey and advocated the study of relevant subjects and vocational education instead of the Classics (Cleverely, 1985).

Overseas Chinese also founded modern and tradtional schools in 
China during this period. Chen Jiageng, a rubber merchant living in Singapore, founded a primary and middle school, as well as colleges for the study of teaching, aquatic science, commerce, and navigation in his home village of Jimei in Fujian Province. He also arranged financial help for other primary and middle schools in Fujian and founded Xiamen University before turning over his projects to the government (Cleverley, 1985).

Education among the illiterate adult population was largely left to dedicated individuals such as Dr. J.Y.C. Yen, who developed a reading scheme based on 1000 characters which could be learned in four months. His textbook, The People's Thousand Character Lessons, was used in the 1920s by secondary school and college students who volunteered to teach hundreds of illiterates in Changsha (Cleverley, 1985).

Reforms were beginning to change the face of Chinese education, but wars, political chaos, and ineffectualness in government prevented a thorough restructuring. Increasing numbers of Chinese scholars studied educational philosophy and administration at American universities, particularly Columbia University. Upon their return to China they popularized the ideas of Dewey, Thorndike, Terman, and others, instigating reforms in methods of teaching and learning (Chen, 1984). Vocational guidance was introduced and coeducation was more accepted. Teaching took a psychological approach and the importance of emotional development was recognized. There were calls for decentralization and community boards of education.

Dewey himself came to China in 1919 and was widely heard and read. His interpretor, Tao Xingzhi, a graduate of Columbia, 
reformulated Dewey's doctrines for China, suggesting that "life is education," and arguing for educational opportunities outside of school, as well as opportunities for ordinary people (Cleverley, 1985). In 1922 the National Education Plan adopted seven objectives: education for social change, democratic education, individuality, economic livelihood, universal education, local adaptation, and education for life. Teacher training for secondary schools was upgraded to university status and degree courses were raised to four years.

MAO AND THE COMMUNIST INFLUENCE

Mao Zedong was the single most influential figure in the creation of a communist system of education in China, retaining authority in the field up to his death in 1976. Born to a relatively well-off peasant family in 1893 in Hunan Province, Mao was sent to school so that he could keep the family accounts. He was a voracious reader who left school at 13 in order to work full time at the family farm. When he was 16 he left home to attend boarding school in a nearby town and in 1913 entered a normal school, attracted by its offer of free tuition and inexpensive board, and his feeling that he was well suited for a teaching career (Cleverley, 1985). He was known as an excellent student, in the subjects he liked, and as a thinker and organizer who questioned traditional teaching methodology and curriculum. He received a degree in 1918 and in 1920 wrote to a friend: "I will hate school for the rest of my life. I have decided not to go to school again, and will study on my own" (Cleverley, 1985). 
In 1919 Mao became a history teacher in Changsha, Hunan Province, but disliked the job because of the poor working conditions. He became active in the United Students' Union which was organizing strikes to oust the loca? warlord. He moved to Beijing where he studied Marxist literature and then to Shanghai where he studied politics. The success of the Bolsheviks in Russia influenced Mao and in 1920 he argued that it was necessary for communists to seize power by force because capitalists controlled the state and schooling and would not give up their hold. He considered Marxism a scientific, flexible, and coherent theory which concerned itself with the exploited and underpriviledged and matched his own sympathies. He stated that while there were thousands of truths about Marxism, they boil down to one: "To rebel is justified" (Cleverley, 1985). By stressing that revolution depends on the will of man as well as social forces, Mao put individual initiative high in the cause of revolution, a position which led him to give education a more important role than earlier Marxists.

Mao was particularly influenced by Lenin, who accepted that schooling must serve the state's political ends in an organized way (i.e., reducing the material gap between urban and rural areas) and take local conditions into account. They both wanted factory-run schools, priority for vocational work at the secondary level, and an end to religious control of schools. They also agreed that literacy was a precondition of political awareness, with illiterates unable to grasp revolutionary theory.

In 1920 Mao returned to Hunan Province and was appointed Director of the elementary school attached to the normal college he had 
attended. He was active in family, school, and community activities and also organized schools for workers' children and evening classes for the parents where education and politics were taught together. He began writing and editing, and, in 1921, he formed the Self Study University with 200 students, regarded as the first training institution for revolutionary cadres in China. Mao's arrest was ordered in 1922 and he moved to Shanghai where he spent several years working on the formation of the Communist Party of China. Between 1929 and 1934 Mao introduced socialist education in Jiangxi Province and helped found the Worker-Peasant-Red Army. In 1934, fearing defeat by the Kuomintang, the communists headed north to Shaanxi Province, one of the poorest areas in

- China. The Long March took over a year. Mao's independent outlook and his questioning of conventional rules lasted into maturity. He placed high value on physical education and health, self study, the importance of non-formal schooling, the need for school materials to reflect local needs, and the important role of student groups in social change.

\section{EDUCATION UNDER THE KUOMINTANG (NATIONAL) GOVERNMENT}

During the 1920s American influence continued by means of Protestant and Catholic missions, which controlled a quarter of the secondary schools and many colleges and universities. The Chinese people, however, were beginning to resent the domination by foreigners and by 1929 about half the foreign missionaries had returned home, leaving their converts in charge (Oleverley, 1985).

With the defeat of the northern warlords by Chiang Kai-shek in 
1928 and the establishment of the Kuomintang government in China (1927-47), education was given the task of promoting a cohesive national state under one party government. The Kuomintang adopted a highly centralized, German-inspired education system, stressing national purpose, work skills, the training of the body and mind, scientific education, and military education (Cleverley, 1985). Detailed laws were prescribed for all levels and forms of schooling and education became highly politicized. In 1930 plans were announced for compulsory education by 1940. Attempts were made to improve conditions for teachers and provincial education offices were required to fix salaries and provide pensions. Teachers were also required to attend courses in anti-communism (Pepper, 1970).

As the Japanese began occupying Chinese territory, as early as the Qing Dynasty, they established schools of their own. In northeast China and in Taiwan the Japanese founded elementary schools which taught the Japanese language, as well as a form of Confucianism. When the Japanese moved south into Beijing in 1937, then to Shanghai, Nanjing, Wuhan, and Guangzhou, the effects on education were devastating. Over 80 percent of China's educational institutions were located in the Japanese occupation zone. As the Kuomintang government retreated west to Sichuan Province, most of China's institutions of higher learning also relocated there. The remainder were taken over by the Japanese. Tens of thousands of school children were evacuated, while others attended the Japanese-run schools. Uncooperative teachers and students were beaten, imprisoned, or shot. Some patriotic teachers ran schools secretly behind enemy lines (Cleverley, 1985). 
During the period of 1937-1945, the Chinese Communist Party established an education system in the desolate Shaanxi-Gansu-Ningxia Border Region of northwestern China, aimed at eliminating illiteracy among the local peasants and soldiers. By 1940 about half the local children were receiving primary education. In addition, specialized schools and institutions of higher learning for training military, political, health, comunication, and teaching personnel were established in the regions under Communist control. Schooling varied from a few months to a year and included night classes, half-day schools, "winter" schools, and other non-traditional forms of education, combining theory with practice (China Handbook, 1983). The lecture method was considered an inferior mode of learning, while debate and criticism were encouraged (Cleverley, 1985).

After 1945 with the removal of the one million Japanese occupying troops, the evacuated schools moved homewards and educational expenditures increased from two percent of the national budget to 15 percent (Cleverley, 1985). Under the Kuomintang, the Ministry of Education began to expand frontier education and radio services, and elementary school enrollments were higher than ever before. However, the shortage of textbooks and trained teachers, especially in rural areas, presented serious problems. China's education was, at this time, largely private, urban, and elitist. In 1949 many teachers fled with the Kuomintang to Taiwan, leaving many of the best schools without faculties (Gamberg, 1977). But, at the same time, there remained a small nucleus of highly trained education personnel, capable of constructing a national education system. 


\section{EDUCATION AFTER LIBERATION}

In 1949, after decades of war and political turmoil, the Chinese Communist Party assumed control of the government of China, a country of about 500 million people, with an estimated 85 percent of adults, 95 percent of the rural population, and 98 percent of the women, illiterate (Arnove, 1984). The education system reached from 25 to 30 percent of the primary age children (Collins, 1981 and Arnove, 1984) and only about 80,000 students were enrolled in higher education institutions. Between 1949 and 1952 the government began nationalizing all public and private schools with the goal of making schools accessible to workers and peasants and their children. An anti-illiteracy campaign for adults was begun with the development of a primer using simplified characters (China Handbook, 1983). Millions of adults learned reading and math skills in winter study classes in 1949, many of them women (Cleverley, 1985).

From the earliest days after 1 iberation there were complaints and dissatisfaction about the hard life teachers experienced. Even though there was a severe shortage of teachers, few people were willing to join the profession. Those who could find other jobs left the profession for a better life, but "those who remained were respected for the sacrifices they made and the hardships they suffered in order to educate the next generation" (Lo, 1984, p. 158).

In the decade following 1949, the Soviet Union served as the model for China in conducting its international and domestic affairs. Teachers and students were directed to honor Russia as teacher and model 
(Chen, 1984). A restructuring of the higher education system forced comprehensive universities to focus solely on sciences and liberal arts, while new colleges and institutes specializing in medicine, agriculture, business, the arts, political science, and normal (teacher) education were established. Many existing educational institutions were moved from the population centers in eastern China to rural, far-off locations in order to provide better geographical distribution. The Chinese government selected students and assigned them to colleges (and major areas of study) and assigned graduates to their work assignments and places of residence (China Handbook, 1983).

The emphasis on Soviet cultural supremacy was accompanied by repudiation of al1 Western influence and of China's past educational heritage. John Dewey was a major target of denunciation (Chen, 1984). Russian replaced English as the most important foreign language. The Sino-Soviet Friendship Association was established, with branches in schools, factories, cities, businesses, etc. Chinese and Soviet students, teachers and workers visited each other's countries. Curriculum content, teaching methods, the grading system, and academic degrees all followed the Soviet model. I. A. Kairov became Chiña's best known educational authority (Cleverley, 1985). Specialized technical training was emphasized over liberal arts.

Many Chinese scholars, teachers, and students were skeptical of substituting Soviet influence for Western influence without regard to making the education system more Chinese. "Never before in the history of education in China had such an extensive effort been made to imitate the education of a foreign country on such a large scale within such a 
short period of time" (Chen, 1984, p. 368).

Ideological and political studies became an intregal part of education at all levels and forms of schools in China, including "spare-time education" (part-time, after work). Learning the tenets of Marxism-Leninism and studying the party and government documents, as well as the speeches of leaders, were required to help build enthusiasm for the new regime and the proletarian-socialist revolution. Developing a class consciousness among all citizens occupied a central place in the ideology. School regulations required that 10 percent of the curriculum be set aside for political and ideological study, though it permeated many subjects, as well as extracurricular activities (Chen, 1984).

The favored classes in the new Chinese society were now the workers, peasants, and soldiers. A new school system formed in 1950 provided special schools for these classes, compressing primary and secondary education into a few years so that adult illiterate laborers might be able to qualify for "higher education" in a short time. At the same time, the regutar schools and universities were ordered to waive entrance requirements and admit those who could never have attended school, let alone higher institutions, before 1949. By 1960 worker-peasant students comprised 90 percent of the primary school population, 75.2 percent of the middle school population, and 48 percent of those in higher education (Chen, 1984). The Chinese Communist Party propagated the idea that Chinese citizens should have strong moral-political motivation in addition to technical expertise. This ideal is expressed in the phrase "red (politically astute) and expert 
(technically competent)." The 1950s saw the beginning of three decades of political turmoil in the realm of education over the proper balance between these two ends (Hawkins, 1982).

The education system in the new China was perceived as an important tool for changing class relations and social attitudes. For schools to be effective change agents, their teachers and administrators had to be politically reliable. For this reason, the new government viewed the existing body of teachers with some concern (Pepper, 1970). Because most teachers came from an "intellectual" background/class and were considered to have liberal education ideas and "feudal" social ideas, the party planned to replace them with a new generation of "working class intellectuals" drawn from more "reliable" classes. Because many teachers had joined or supported the Kuomintang (though the majority were passive or demoralized), there was a plan to replace them with members of the Chinese Communist Party (Pepper, 1970).

Following nationalization of the schools (1949-1952), during which time many schools were closed, a second period of educational reform (1953-57) resulted in expansion of primary and teacher education, 1iteracy education, on-the-job education for workers, and distinction between polytechnical and comprehensive colleges and universiies (Hawkins, 1982). The number of students in primary and secondary schools and higher education tripled and quadrupled, while illiteracy dropped significantly, in spite of a shortage of middle and upper secondary schools and teachers (China Handbook, 1983). A variety of new forms of education developed, including radio broadcast schools and correspondence schools. Education was extended to minority peoples, the 
54 nationalities comprising about six percent of China's population. Factories, mines, and communes used their own resources to open schools (called "minban," people's schools) combining labor with education. The State Council stated that "education must be combined with productive labor" and that "everyone who receives an education [should be enabled] to develop morally, intellectually, and physically" (China Handbook, 1983). These three characteristics became known as the "three-goods." The mass enthusiasm of the winter school movement of 1949-50 was difficult to sustain, however. Many learned and forgot, while others dropped out. The task of learning 5000 to 8000 Chinese characters necessary for a reasonable grasp of the language proved too difficult for many. Important decision-making posts were held by people with the lowest of educational qualifications (Cleverley, 1985). Dialects predominated in most of China and language reform was encouraged. In 1955 the northern dialect known as Mandarin was declared the common 1anguage of China, "putonghua." With "putonghua" came sets of simplified characters which reduced the number of brush strokes needed to write familiar words. In 1958 the phonetic roman script, "pinyin," was approved as an aid to pronouncing "putonghua." It was said that the adoption of "pinyin" would reduce by two years the time required for children to learn to read (Cleverley, 1985). However, after 1957 the language reform movement lost momentum and dialects remained widely spoken.

The early years of the Chinese Communist Party government were generally successful in that peace prevailed and access to education widened. Living conditions for women and children improved as food and 
clothing were rationed and underutilized accomnodations were requisitioned. Schools for homeless children were formed. Children's books were published, radio networks established, cultural and sports facilities expanded, and theater, opera, music, and films were popular.

In 1956 the "Hundred Flowers" or "Double Hundred" campaign was instituted with the purpose of eliciting criticism of the government and its policies and prograns from China's intellectuals, including, of course, teachers. Public speeches and broadcasts criticized Mao and the Communist Party for creating a new privileged class and government corruption. Some called for the return of Chiang Kai-shek. This was followed by an "anti-rightist" campaign in 1957, when the CCP realized that many intellectuals did not appear to value combining redness with expertness (Hawkins, 1982). Many teachers "lost their enthusiasm for education" and "the one sided stress on education serving proletarian politics and the integration of education with productive labor ${ }^{n}$ led to a deterioration in educational standards, as students and teachers had devoted too much time to production and social and political activities (China Handbook, 1983). At least 300,000 "rightists" were counted, with the most prominent group being teachers, many of whom were sent to rehabilitation farms or jails, and, in some cases, shot (Cleverley, 1985).

Mao Zedong retired as Chief of State in 1958, to be succeeded by Liu Shaoqi, but remained Chairman of the Party. Liu and Mao differed fundamentaliy on educational policy. Liu and his supporters believed that China's limited resources must be mobilized for modernization. Concentrating on the ablest students' education would help overcome the 
country's backwardness. Once China had progressed, education could be broadened and made universal. Mao and his party, on the other hand, maintained that the perpetuation of an educated elite must be avoided at al1 cost. A truly egalitarian society based on a "new type of human being" was the only guarantee of the continuance of the new state already founded on socialist economics (Morton, 1980). Education was vital to this goal, but it had to be a new education, less academic, more linked to work in the real world. Increased skills through education for everyone would strengthen the development of the nation. "Red" was more important than "expert." Mao won.

In 1958 China entered a third phase of educational reform, part of the period known as the Great Leap Forward. Mao and other leaders introduced reforms aimed at decentralization of planning, the introduction of communes, and infusing politics into every level of schooling, i.e. leaning more toward redness. A severe drought between 1959 and 1961 brought mass starvation and abandonment of expanding educational enrollments. In 1960 the Soviet Union removed all its experts from China after several years of worsening relations. This, along with a continuing blockade from the West, resulted in China's complete self-reliance in most areas of development, especially education (Hawkins, 1982). Between 1961 and 1962 the Ministry of Education formulated national policies for primary, secondary, and higher education with regulations, objectives, curricula, and research goals for each. Textbooks for 12 years of study were compiled, along with texts for the universities. Teaching plans were written for use throughout the nation (China Handbook, 1983). 
The period from 1962 to the eve of the Cultural Revolution (1966) was characterized by a return to quality, or expertness. In education this meant greater emphasis on formal schooling, and restrictive enrollment in "keypoint" schools (precollegiate and collegiate "model" educational facilities that are of higher quality in terms of facilities, funding, teaching staff, and student body and which perform a screening function, tracking the more able students into universities) resulting in a widening gap between rural and urban educational and social indices (Hawkins, 1982). The number of institutions of higher education had doubled since 1949 and the number of university students had quadrupled (China Handbook, 1983).

THE EFFECT OF THE CULTURAL REVOLUTION ON TEACHERS AND EDUCATION

The complex and bitter struggle of the Cultural Revolution (1966-1976) resulted in a negation of much of the experience and achievement of China's recent 17 years of educational reform (China Handbook, 1983). Teachers were among those who were humiliated and attacked, often physically, as bourgeois intellectuals who had been trained in the "old-type schools" and now needed to learn from workers and peasants (Lo, 1984). Universities and secondary, vocational, and part-time schools were closed, books and equipment were destroyed, and entrance examinations were abolished. Many professors, as well as a number of school administrators, teachers, and students, were sent from their jobs and families to live in rural poverty while they worked at hard labor and reformed themselves. Many were also killed or committed 
suicide. Thus, teachers who had already been given insufficient material rewards were now deprived of even the respect tradionally accorded them. "It is unfortunate to become a teacher" was the popular feeling among teachers (Lo, 1984).

Teachers had no desire to resume teaching under the hazardous conditions of the late sixties. For several years the reopening of schools was sporadic. Some primary schools opened with makeshift programs, while many children were taught at home. In 1970 some universities reopened to admit workers-peasants-soldiers. Qualifications were based on work experience and revolutionary record. These irregular admissions practices, often tied to family connections or favors owed, were referred to as "taking the back door." They persisted, in some cases, until 1977 (Unger, 1982). New schools openty discriminated against the bourgeoisie and their children. There were no prescribed curricula, no standards, and no grades given. "Revolutionary work," such as mass campaigns denouncing Confucius, was considered more important than study. All education was supposed to serve practical and immediate needs and academic scholarship was scorned (Chen, 1984). Mao made many statements that discouraged the study of books. Of schools he said, "First, there are too many classes; second, there are too many books. Real understanding must be acquired gradually through the experience of work" (Chen, 1984).

Workers, peasants, and soldiers became teachers at schools and universities. Thousands of Mao Zedong Thought Propaganda Teams took administrative posts to make sure that ideological-political training in the classroom would follow Mao's teachings. These teams supervised the 
curriculum, the faculty, and students, even though many of them were illiterate. Intellectuals were now regarded as the most despicable class in Chinese society (Chen, 1984).

By 1975 voices were being raised in criticism of the educational system as it was being administered by proponents of the Cultural Revolution. University officials wrote to Mao saying that if the system was not changed, "people will be leaving the universities without being able to read a book" (Morton, 1980). On the other hand, articles defending the system were printed. Mao's wife, Jiang Qing, came under criticism and Deng Xiaoping became more influential. It was a period of internal party struggie.

Mao Zedong died in 1976, opening the way for sweeping changes in leadership, beginning with the overthrow of his widow and her associates, the Gang of Four. The new leaders quickly announced a turnabout of ideological-political emphasis from revolution to development. It was now decreed that the primary task of education was to train the personnel needed for the "four moderizations" program.

\section{POST-MAO EDUCATION IN CHINA}

Post-Mao schools are quite different from those of pre-cultural revolution education. The conventional, full-time school is again the mainstay of Chinese schools. The main task of students, said Deng Xiaoping, is "to study, to learn book knowledge," and the task of schools is to make "strict demands on students in their study" (Chen, 1984). Examinations have returned with more emphasis than ever before. 
Selective education weeds out students who are not "academically qualified," and special privileges for workers-peasents-soldiers have generally disappeared.

The starting point for the post-Mao leadership was a reevaluation of the pre-Cultural Revolution education system and the role of the intellectuals. The 1949-1966 period in education is now viewed as a positive one. Intellectuals have now been categorized as a section of the laboring people (Rosen, 1981). The separation of those engaged in mental labor from those in manual labor is no longer to be emphasized as a key division in Chinese society. Hua Guofeng, Chinese Communist Party past chairman, stated, "The masters of our socialist society are the socialist workers, peasants, and intellectuals, and those other patriots who support socialism" (Rosen, 1981). The rehabilitation of the - intellectuals and the new party line regarding class coincided with a renewed stress on academic achievement. The Teadership of China mourned the ten wasted years of 1966-1976 and sought to make up lost time.

Today in China, approximately 183 million children between seven and nineteen attend primary and secondary schools, and of these, 136 million are primary students (Johnson, 1986). This number is estimated to be 90 percent of those eligible to attend primary schools, in contrast to the pre-1949 figures of 40 percent of urban children and five percent of rural children, a total of about 24 million (Cowen and McLean, 1984). Primary school is general1y five years, except for the cities of Beijing and Shanghai where $i i$ is six years. It is estimated that of the 60 percent of rural students who graduate from fifth grade, only about a third have real primary school competence due to the poor 
quality of most rural schools. There is also a common belief in many families that it is better for children to work in the fields and add to the family income, than to attend school (Butterfield, 1982). Girls are more likely than boys to leave school.

China's secondary schools, generally referred to as middle schools, are divided into three-year lower (or junior) secondary schools and two or three-year upper (or senior) secondary schools. In 1949, about one million students were enrolled in secondary schools. Current estimates of enrollment range from 47 million (Johnson, 1986) to 58 million (Cowen and McLean, 1984) to 65 million (Hawkins, 1982). However, only a fraction of these students, about one million, attend vocational or technical middle schools (Hawkins, 1982, Johnson, 1986).

Six to seven million students graduate from "ordinary" senior secondary school each year (Hooper, 1985). The situation facing these schools is that only four percent of graduates can find openings into colleges and universities, about one percent of the relevant age group (Hooper, 1985 and Hawkins, 1982). In spite of the expansion of tertiary institutions since 1949, only 350,000 new students are admitted each year. The millions of urban graduates who cannot find a place in higher education have few options. They may continue to study for the exam and try again the following year, attempt to enter a vocational training institute, find their own jobs, or wait until the government assigns them a job (Hooper, 1985). In a country of over one billion people with only seven million college students, higher education is valued highly as the road to the reward of preferential occupations (Hawkins, 1982). As early as nursery school and kindergarten the competition begins to 
gain admittance to the "right" school, a "key" school.

"Keypoint" or "key" schools were revived in 1976 to serve as models for other schools to emulate. Denounced as elitist during the Cultural Revolution, these primary and secondary schools and colleges and universities are to be "provided with funds for well-equipped laboratories and libraries and staffed with highly qualified teachers able to stimulate gifted students to develop their talents and potentialities" (Chen, 1984, p. 380). A hierachical ranking has been built into the keypoint system itself, with national, provincial, municipal, and district keypoints receiving variable funding and facilities. Most are located in urban centers. In order to qualify for entrance to one of China's 700 tertiary institutions, a student has little chance of passing the university entrance examination unless he/she has attended a keypoint high school. China has about 6,000 keypoint high schools, about five percent of the total (Hooper, 1985).

Perhaps the most innovative feature of China's educational experience over three decades has been its complex alternative education mechanism of nonformal education, which currently enrolls about 30 percent of the urban workforce (Hawkins, 1982). Television courses, correspondence courses, and night classes are currently providing educational opportunities to large sectors of the Chinese population. Nonformal agricultural universities and colleges have been designed to offer flexible courses of study in order to supply skilled human resources for China's rural mechanization. Short term training and education extension activities have brought scientific farming techniques and literacy to rural populations. 
However, according to the 1982 census, there are still 238 million illiterates in China, 70 percent of whom are female (Hooper, 1985 and Cleverley, 1986); most live in rural areas. Illiteracy has been defined as "knowing fewer than 1500 chinese characters and being unable to read a simple book or newspaper or write a simple message" (Cleverley, 1986).

In post-Mao China, the growth of a national elite for the benefit of modernization is seen as different from the elitism of bourgeois society. Higher education institutions are not ladders for only the privileged to climb, but for all citizens, according to Hua Guofeng (Hawkins, 1982). Chinese officials say that over the past thirty years the opportunity structure in education has been equalized and that extremes of social class are relatively absent. Stil1, it seems obvious that China is concentrating its educational resources on a relatively small number of urban students, three-fourths of whom are male (Hooper, 1985, Thogersen, 1986, and others).

China's size makes central planning very difficult. There is a continuing wide gap between large cities and rural areas and poorer provinces. The four areas given priority for modernization, outlined by the government in 1978, include agriculture, industry, national defense, and science and technology (Chen, 1984). In 1978, at the National Education Conference, Deng Xiaoping stated that educational policies must be changed in order to train and promote more and better qualified people to meet the demands of the Four Modernizations.

With huge demands on the treasury for these priorities, only limited funds have been available for education. While Japan spends 30 
percent of its gross national product on education, China spent 1.7 percent from 1950 to $1965,1.10$ percent from 1966 to 1976 , and no more than 1.12 percent in 1977-78 (Chen, 1984). In 1980, the Chinese national budget for culture, public health, science, and education combined amounted to only $\$ 10$ billion, according to government figures (Collins, 1981). These funds were to serve more than $200 \mathrm{mill}$ ion students in primary schools through university. In 1982 China ranked 110th on the United Nations list of spending for education (Butterfield, 1982). To make up for the shortage of funds for education, most local governments have increased their education funding, especially to refurbish school buildings and improve facilities (Li Xing, 1987). Outside of the state-supported schools are the "minban" (people's schools) which are locally supported. Two-thirds to three-quarters of al1 rural teachers are "minban" teachers, many of whom have no more than a primary education. While there is a national regulation requiring "minban" teachers to pass an examination in order to be recognized as qualified, they can continue to teach until they can receive training to pass the examination (Mauger, 1983). These teachers have, as one educator explained, "no training, no teaching materials, no status, no job security, and often no reliable income" (Brown, 1986). Most rural teachers receive a distribution of money and grain comparable to a peasant laborer and some provinces report teacher salaries lower than any other incomes. Surveys have also reported teachers going without pay for as long as a year-and-a-half (Brown, 1986). The turnover rate has been very large, with many of the best-educated teachers applying for other jobs or going on to further study. 
The 1986 compulsory education law, experts point out, will be impossible to implement without millions of additional teachers (Zhang, 1986). China's goal is for every school-age child in China to receive nine years of schooling by the year 2000 (China Data, 1986).

THE STATUS OF THE TEACHING PROFESSION IN CHINA

The reluctance on the part of the Chinese government to invest heavily in education may reflect a lingering lack of confidence in intellectuals, particularly teachers, who tend to preserve the traditional educational values, as well as in foreign influences which have left their mark on Chinese education over the past century (Cowen and McLean, 1984). "Teachers hold the key to the success of a schoor in training qualified personnel for the proletariat; namely, workers with both socialist consciousness and culture who are developed morally, intellectually, and physically," Deng Xiaoping stated in 1978 (Lo, 1984, p. 154). In spite of admonitions by government leaders that students and communities must respect teachers, the profession of teaching, so vital to China's development, has suffered terribly in the past $\mathbf{3 0}$ years.

The status of teachers in China fell to an all-time low during the Cultural Revolution, when many of them were attacked, persecuted, and replaced by untrained workers and peasants. Teacher morale and relations between students and teachers had been deliberately destroyed by the Gang of Four. Teachers were called "scum of the earth," "maggots," and "flies fattening on the morsels of stinking revisionist 
meat" (Cleverley, 1985). In spite of the present government's efforts to give teachers a more favorable public image, the country's present ten million teachers still often face hardships such as housing shortages or poor quality housing, limited time for leisure and self-improvement, and poor working conditions (Zhang, 1986). Bureaucracy, inefficiency, and overcentralization of power plague schools, admitted Li Peng, Vice-Premier, at the September 1986 Teachers' Day award ceremony (Zhang, 1986). But it is the poor social status and low pay that are most responsible for the shortage of qualified teachers in China (Johnson, 1986, Cowen and McLean, 1984, and others). Negative social status is expressed in many forms. Parents who were once teachers themselves strongly oppose their children becoming teachers because of the suffering they have experienced (Lo, 1984). There are reported instances of teachers being discriminated against when applying to join the Communist Party (Lo, 1984).

In an attempt to raise the status of teachers and inspire young people to enter the profession, the Chinese government has applied various measures. Teachers have "been given the glorious titles of 'People's Soul Engineers,' 'Gardeners,' and 'People's Heroes'" (Lo, 1984). In 1985 the government introduced "National Teachers' Day" and directed students to honor their teachers with gifts and other forms of appreciation (Johnson, 1986). Ceremonies are scheduled at the national and local levels and medals and certificates are awarded. Posters show teachers being saluted and presented with bouquets of communes, enterprises, etc., have been unavailable, but in 1979 they contributed 36 percent of the total expenditure on education (Bastid, 1984). 
Traditionally, China's teachers earned more than workers and peasants. Today, however, most teachers, receive salaries much lower than those of workers who have the same qualifications and number of years of working experience (Lo, 1984, and Collins, 1981). This is true not only for primary teachers (high school educated), but secondary teachers and college teachers, as well. National1y, primary and secondary teachers' average monthly salary is US\$24 (88.23 y), with a 10 percent pay raise due in summer of 1988 (Guo, 1988). In Beijing, the average is US\$30 a month (Johnson, 1986). However, workers have access to better housing and medical care, generally supplied by employers, and are eligible for bonuses which can add 15 percent to their incomes.

Attention is being given to ways of making the teaching profession more attractive, especially in remote and poor areas. Primary and secondary teachers can earn bonuses according to seniority and those assigned to work in certain border areas are now allowed to return to their original places of residence. In some schools bonuses are given based on the number of students who have passed the national university examinations. Holidays and free time are expressly stipulated and are longer than in past years. Teaching loads have been defined, though class size remains large, between 40 and 50 students, even in keypoint schools (Johnson, 1986).

In a developing country like China, people with relatively good education are needed in many sectors of the economy. The Four Modernizations efforts are creating more alternative occupations where both the financial returns and prestige are higher, discouraging teachers from staying in the profession. Changing occupations has been 
almost impossible in China, due to the "danwei," a system of social control. Theodore White (1983) describes the system:

Everyone in China must belong to a factory, neighborhood, peasant, or office danwei. The danwei controls your life. The neighborhood danwei assigns you to a job; then you belong to a factory [or office] danwei, which decides when you can have a baby and how large an apartment you live in. It can also transfer you to a danwei in a distant province and your [spouse] to another. And so, up the line, to absolute control (p. 48).

The danwei system has prevented an even more severe loss of teachers to other professions (Lo, 1984). In the rural areas, however, teachers may return to farming without government permission. New economic policies allow private plots and share-cropping, making farming a more remunerative and respectable profession (Hooper, 1985, and Lo, 1984). A recent survey of Shanghai teachers revealed that one-third wanted to change jobs, primarily due to the low standard of living (Guo, 1988).

\section{TEACHER EDUCATION IN CHINA}

The field of teacher education also suffers from poor status within Chinese society. Recent reports indicate that the quality of students in teacher training institutions "limits the achievement of the aims of teacher training" (Lo, 1984).

There are three levels of formal teacher training institutions: 1) higher education teacher training institutes with a four-year program training senior middle school graduates to teach in senior middle schools or colleges; 2) teacher training schools with a two-year program training senior middle school graduates to teach in junior middle schools; and 3) secondary teacher training schools with a three-year 
(high school) program training junior middle school graduates for teaching in primary schools or kindergartens (Cowen and McLean, 1984).

What many of these institutions have in common is a student population which has failed to enter more prestigious higher education institutions and secondary schools. Many students recruited into teacher education have a strong sense of failure, especially those at the four-year colleges or universities who see themselves as "university failures" (Lo, 1984).

Survivors of the university entrance exams are eligible for enrollment in one of China's 700 tertiary institutions ranging from top key universities such as Beijing University, Fudan University, and the top language and technology institutes to provincial universities and lower status teachers' universities and colleges. Students may list five places. The most favored fields of study are those areas in the forefront of China's modernization: science and technology, computer studies, and engineering. English language study is also a preferred field. Choosing a university and a major are gambles because of the quotas. There has also been blatant corruption, such as "use of personal relationships" (the backdoor) and "examiners, educational officers, and university administrators tamper[ing] with students' examination results... in response to approaches and bribes from influential people" (Hooper, 1985, p. 51).

Besides exam scores, universities also take into account school records, sports ability, moral conduct, and health (those with physical handicaps, partial blindness, or hepatitis-related kidney/liver disorders are generally not accepted) (Hooper, 1985). A background in 
the Communist Youth League is an asset. Males are about three times as likely as females to receive a higher education. In 1982, women represented up to 50 percent of the student body at some teachers colleges, but only about 16 percent at top technical institutes (Hooper, 1985)

According to a 1986 survey at Beijing Teachers College, of the 3,000 applicants for the school, only 57 were qualified. Even when the college lowered its standards for admission, it was unable to fulfill its target of recruiting 800 freshmen (Zhang, 1986). Due to the shortage of higher education opportunities, even many students who pass the exam with high marks find themselves enrolled in teachers colleges against their will. Many do not study or attend class, looking for ways to "escape teaching" (Lo, 1984). Others who do complete their teacher training and are assigned teaching jobs, often do not show up for work or find other jobs (Johnson, 1986).

Not only do recruitment policies make it difficult to develop a professional identity in teacher education students, but low standards in recruitment also make it difficult for training institutions to produce competent teachers. A sizabie number of teachers assigned to teach in upper secondary schools, have been found to lack upper secondary school level knowledge themselves (Lo, 1984). As a result, many institutions devote most of the teacher education curriculum to developing specialized subject knowledge.

Teacher colleges have made efforts to convince students that teaching is a "glorious profession" through such activities as convocations and opening ceremonies (Lo, 1984). Tuition is free at all 
Chinese higher education institutions, and at teachers' colleges even food and books are subsidized (Cleverley, 1985).

In addition to combating the idea that "teaching is useless," teacher training institutions have been criticized for their insufficient preparation of students (Zhang, 1986). Educational psychology and pedagogy are not given proper emphasis, the State Education Commission says, with the result that many teachers fear teaching secondary school students (Zhang, 1986). In fact, pedagogical courses are not offered at many teacher training institutions and teaching practice is, similarly, deemphasized at most, with the result that most students have a few weeks, at best, to practice developing and teaching lessons (Lo, 1984).

Since most primary and secondary schools gear their curriculum and teaching towards entrance examinations, heavy stress is placed on achievement in academic subjects (math, Chinese, politics, geography, English, history, natural science, chemistry, physics, and biology) (Lo, 1984). The teachers they require must be knowledgable in these areas. Teacher training institutions, therefore, are under pressure to produce students with competence in these subjects, as opposed to developing other qualities (Lo, 1984).

The Ministry of Education has advocated an "ideal curriculum" for teacher training institutions, which includes the following four parts: 1) Political theories and other fundamental courses, 2) pedagogical studies (including psychology, pedagogy, teaching methods, etc.), 3) courses in specialized subject areas, and 4) teaching practice (Lo, 1984). In actuality, subject area study is stressed almost to the 
exclusion of the other parts (Bastid, 1984).

There has been a tendency for many higher level teacher training institutes to devote a disproportionate amount of time and effort to research and specialization in fields unrelated to school teaching, thus playing down their teacher-training character (Lo, 1984). While this has been criticized by some, it has been supported by others. The unfortunate effect will be that of preventing the best students from becoming teachers. Many teacher training institutes have a policy of keeping their best students as researchers or instructors in specialized fields. Since most have not entered the training institutions willingly, these positions allow students to further their studies in their own specialized fields and provide higher prestige than secondary school teaching (Lo, 1984).

In spite of various methods of increasing teacher training opportunities, China has a critical shortage of adequately prepared teachers (Bastid, 1984, and others). Data from Lo (1984) in Table I indicate the severity of the probiem and also reveal the after-effects of the Cultural Revolution on teacher retention.

Higher education does not fare much better as far as the qualifications of the teaching staff are concerned. From a survey conducted in 1979 in 20 keypoint institutions, less than eight percent of the university staff had completed six years or more of higher education (not all including postgraduate work) and 16 percent had three or less years of higher education (Bastid, 1984). Many higher educators had ceased academic activity during the cultural revolution when large 
TABLE I

\section{PERCENTAGE OF QUALIFIED TEACHERS $1965-1980$}

$\begin{array}{cccc}\text { Year } & \begin{array}{c}\% \text { of Qualified* } \\ \text { Primary } \\ \text { School Teachers }\end{array} & \begin{array}{c}\% \text { of Qualified* } \\ \text { Lower Middle } \\ \text { School Teachers }\end{array} & \begin{array}{c}\% \text { of Qual ified* } \\ \text { Upper Middle } \\ \text { School Teachers }\end{array} \\ 1965 & 47.5 & 71.9 & 70.3 \\ 1973 & 28.0 & - & -3 \\ 1977 & - & 14.3 & 33.2 \\ 1979 & 47.0 & 10.6 & 50.8 \\ 1980 & 47.0 \text { approx. } & 10.0 \text { approx. } & 50.0 \text { approx. }\end{array}$

*Qualified is defined as completing the appropriate training program suggested by the Ministry of Education. (Lo, 1984) 
numbers of poorly qualified, but poiitically favored, young "assistants" were brought in. These people, some of whom have developed into excellent teachers, remain and are protected by the CCP because of their proletarian origin and Party membership (Bastid, 1984).

Since higher education has, so far, been limited in its attempts to provide teachers for the nation's secondary schools, government authorities are encouraging other means of recruitment and retention. A recent Beijing newspaper article (Zhang, 1986) proposed these suggestions: 1) Teachers' colleges should choose students who want to devote themselves to education; 2) The government should reward advanced teachers and all those engaged in education; 3) Society should support teachers in their work and lives; 4) Local authorities should provide more incentives to boost enrollment at teacher training schools; 5) More higher education institutes should offer two-year training programs; and 6) Qualified self-taught students and students of television universities should be assigned teaching posts. While these suggestions are beginning to be implemented, the majority of China's teachers are being trained at the inservice level through nonformat means (Lo, 1984).

In the past ten years the Chinese have established special kinds of training institutes called "Jiaoyu Xueyuan" (colleges of education) and "Jiaoshi Jinxiu Xueyuan" (schools for teacher refresher courses) which provide inservice training to teachers. Approximately 4,000 such colleges and schools at provincial, prefectural and county levels are providing training for on-the-job teachers (Lo, 1984). In contrast, the total number of existing regular teacher training institutions is 1,189 
(172 higher education teacher training colleges and 1,017 secondary teacher training schools) (Lo, 1984). The number of colleges and schools providing inservice training to teachers is more than three times the number of those providing preservice training.

The much larger number of inservice colleges and schools of education also train more people. At present, approximately one million secondary school teachers (of a national total of 3 million) and 2.5 million primary teachers (of a national total of 5.5 million) are enrolled in some kind of inservice training (Lo, 1984). Only 790,000 future teachers are being trained in the 1,189 preservice training institutions (Lo, 1984).

China's policy makers have disagreed over methods of implementing nonformal education and the relationship between this form and the more formal kind, but none have disagreed with the principle that Chinese education must "walk on two legs" - the leg of formal, selective education and the leg of nonformal, flexible and open education (Hawkins, 1982). Teacher education seems to have been assigned to nonformal status.

In 1980 the Ministry of Education announced that it would administer the six higher teacher training institutes (keypoints), while the provinces, municipalities, and autonomous regions were each directed to establish a higher teacher training school and a few secondary (normal) teacher training schools (Hawkins, 1982). For inservice education, each province, county, and municipality was also directed to establish a college of education, and each prefecture a school of education. All teachers must pass a verification examination before 
receiving a teaching credential. The role of the Ministry of Education was to be guidance and direction. Thus, while teacher education has increasingly become a national concern, local authorities would need to take responsibility for the actual provision of teacher training (Lo, 1984). While autonomy in running teacher training programs allows variation for local needs, such as training of teachers for minority groups, there is a fear by some that local modifications may hinder the realization of China's educational goals.

To summarize, most teacher training in China can be described as localized, subject matter oriented, and with a nonformal inservice format. It is doubtful that this kind of teacher training is capable of preparing teachers for more demanding educational roles. While emphasis on subject matter seems necessary to raise the educational level of those in training, the remedial nature of the inservice courses cannot be construed to be teacher training (Lo, 1984). The importance of pedagological coursework, while recognized by many educational authorities, is still given little attention by many institutions, and it appears that the development of formal preservice training programs has been curtailed in favor of the "quick and economic" inservice training courses (Lo, 1984). In fact, educators in China are now advocating the institutionalization of inservice teacher training with a system of assessment. Teachers may pursue their studies in various ways and then take exams for one or more subjects. For each subject they pass, they are awarded a certificate. After passing all the required subjects they may be given a diploma and will be considered a college graduate (Lo, 1984). 
QUALITIES OF AN IDEAL TEACHER

The desirable qualities of an ideal teacher in ancient China include many of the traits which are still being advocated today. These include competence in subject matter, teaching ability, and moral character. Even after the Communist regime, the ideal teacher was to have these traditionai qualities along with one more: that is, dedication to communist ideology and willingness to serve the people in spite of hardships (Lo, 1984).

Changes in educational policies after the fall of the Gang of Four have called for a new definition of a "good" teacher, systematically summarized in a section of the "Temporary Regulations for Full-Time Secondary Schools" (Lo, 1984, p. 156-157): 1) The ability to teach academic subjects we11. (The teacher must "equip students with advanced scientific knowledge." To do this a teacher must take an active role in preparing lessons, marking exercises, and assisting students. It is emphasized that teachers should be allowed more freedom to do their job than in past years); 2) A love for students. (Teachers should guide students with patience and appropriate methods. Teachers should understand students' problems in daily life and in school and be responsible for their all-round development); 3) Willingness to be a moral example. (Schools are urged to set strict standards on teachers' "moral and cultural training, lifestyle, behavior, and learning aptitude." School administrators should not criticize teachers in front of the students); 4) Professional competence. (Teachers are urged to "master the tools of pedagogy, psychology, and physiology." A good 
teacher should constantly improve himself in the mastery of subject matter and pedagogical practice).

The "ideai" teacher in the post-Gang-of-Four period is different from the "ideal" in any other period since 1949. There is a return to stressing the traditional values, but not so much emphasis on ideological Marxist commitment. However, they should still "work hard without thought of personal profit or fame" (Lo, 1984). Beyond the official definition of the "ideal teacher" is the one with which school administrators and teachers must live. The reputation of schools tends to rest on the success rates of those students passing examinations. The teachers in the top grades of primary schools, lower secondary schools, and upper secondary schools (the grades in which students take exams) tend to be there because they have proved their ability to get a high proportion of students through the exams (Dove, 1986). These teachers enjoy higher status in the community and are likely to have better than average promotion prospects within the school. In contrast, teachers in lower grades or in non-exam areas of the curriculum do not have, such opportunities (Dove, 1986). Thus, the qualities of the ideal teacher in China's schools are, in reality, tied to student success rates.

THE SCHOOL CURRICULUM AND TEACHING METHODOLOGY

Since the establishment of the new republic, educational leaders have grappled with three major curricular questions: 1) Who controls curricular revision and development? 2) What should be taught? and 
3) How should the material be presented? (Hawkins, 1983). Over the past three and a half decades the answers have varied due to the struggle between ideology and practicality.

Generally, educational materials in China have been developed by various educational ministries and authorities, without regional input. Mao criticized this approach, advising that if peasants had no control over curricula, they would not encourage their children to attend schools (Hawkins, 1983). Control over the curriculum, teaching materials, and teaching methods shifted back and forth from localities to the central Ministry of Education in Beijing. The Cultural Revolution ended the role of the formal educational bodies and meant that local schools, teachers, parents, and even students now played a role in curriculum development and reform. However, the turbulance of the times prevented any real innovations and the few teachers remaining in the schools were not adequately prepared for the role of leadership in curriculum planning (Hawkins, 1983).

The current Four Modernizations Movement has restored central control over school curricula. Curriculum materials are provided by the state, developed and tested by the Ministry of Education, printed by the central government, and distributed to the localities through the provincial, county, and municipal authorities. Foreign curricula are also being utilized, particularly in the areas of science and technology. While regional inequities continue, especially in border/minority areas, there is a move toward a unified, integrated national curriculum for China's schools.

However, it has been observed that very few members of the 
committees in charge of designing new curricula are competent to draw up the kinds of programs that can meet present or future needs, and many promising proposals have been defeated by members who failed to understand their importance (Bastid, 1984). In addition, constantly shifting policies, which have resulted in feuds, rivalries, and resentments, continue to interfere with implementation of policy in schools, although this may slowly subside as genuine elections and 1 imited-term mandates are carried out (Bastid, 1984). As for teacher participation in curriculum planning, Hawkins (1983) observes, "It will be important in the 1980s to learn whether Chinese educational leaders will only permit use of a ministry-approved curriculum or if teachers will be allowed to augment standardized materials with ancillary materials of some sort."

When examining the curricula of a nation's school system, it is important to examine the officialiy-stated goals of education. The purpose of primary education in China is

to cultivate in the pupils the moral character of loving the motherland, the people, physical labor, science, and public property, cherishing socialism, and supporting the Communist Party; to help them to acquire the ability of reading, writing and arithmetic, fundamental knowledge in natural and social sciences, and good study habits; and to enable them to enjoy good health and acquire fine habits in life and labor (China Handbook, 1983, p.35-36).

At the primary school level the nationwide course of study centers on Chinese language and math, which take up about two-thirds of the instructional day. Natural and social sciences make up about a tenth of the school time, with the rest of the day used for art, music, and physical education. Foreign language (generally English) is offered in the upper grades in most key schools in urban areas. Another eight 
hours a week are devoted to extracurricular activities such as sports, Young Pioneer scouting events, and productive labor (deemphasized since the 1970s). At the primary level, the course of study may be adjusted by local authorities to meet specific regional demands, such as teaching the languages of minority groups (Hawkins, 1983).

The purpose of "ordinary" secondary school education is

to cultivate in the students patriotism and communist ethics; teach them gradually to foster the proletarian world outlook on life and work for the people and the modernization of the country; help them to do a good job in studying and mastering the elementary knowledge of science and technology and culture; and ensure them a normal development in body and mind and enable them to acquire aesthetic judgement and labor skills (China Handbook, 1983, p. 38-39).

At the lower secondary school level the nationwide curriculum devotes about 35 percent of the school day to Chinese language and math, about 15 percent to foreign language (English), and about 50 percent to nine other subjects including sciences and physical education.

Extracurricular activities are also offered.

Upper secondary school students spend about half the school week studying science and math, 30 percent on Chinese language and a foreign language, and 20 percent on three additional subjects, generally sciences. Since few schools have laboratory equipment, science study is largely theory. Keypoint secondary schools, as well as many regular secondary schools, divide students into ability groups, with the "fast classes" receiving additional attention from teachers (Hooper, 1985).

In addition to "ordinary" seondary schools are the specialized secondary schools whose purpose is

to train specialized personnel with political awareness and professional proficiency. The end product, being morally, intellectually, and physically fit, will ably contribute to the cause of the socialist modernization. The schools shall see to 
it that the students will have communist morality, support the leadership of the communist party, love socialism, and are determined to serve the socialist cause and the people. At the same time they shall attain the level of a senior middle school education. They shall master the basic theories and specialized knowledge of their own fields and and have practical skills (China Handbook, 1983, p. 42-43).

Specialized senior secondary (middle) schools include normal schools for the training of primary teachers, and technical schools for the study of engineering, forestry, agriculture, business administration, political science and law, physical culture (sports, drama, dance, and music), and art. Courses include general knowledge, politics, basic professional knowledge, and specialized skill. Most schools are residential and offer free tuition and subsidies from the state.

Despite revolutionary rhetoric and massive social-change, Chinese teaching methods have remained surprisingly traditional (Hawkins, 1983). The teacher-centered classroom with students cast as passive recipents of knowledge has remained the norm. - Ironically, it was Mao himself who criticized the "injection method" in education, referred to as "stuffing the duck," and urged teachers to abandon the traditional rote methods and move toward more group discussion, problem solving, and open-book tests Shirk, 1979). In one of his more critical talks he advised,

The students should be allowed to doze off when lessons are taught by teachers. Since you are unable to teach we11, rather than to require others to listen to your tasteless lectures, it is better to doze off and take a rest. The students refuse to Tisten to you when you just make a lot of noise (Hawkins, 1983, p. 428). 
For many teachers, primary through university, learning to stimulate students and involve them in classwork are new skills which require remedial training. The majority of teachers have not even allowed students to ask questions in class, for fear they might suffer the embarrassment of not knowing the answer (Johnson, 1986).

Because exams serve to allocate life-chances in China, they are very important. The Chinese have had centuries of experience with exams and they are still perceived as the fairest means available of rewarding merit. There is a fear that without them teachers will "lack motivation, direction, and a sense of standards to attain" (Dove, 1986). But exam pressures affect the way teachers manage the curriculum and interact with students. In addition, exam questions have tended to test the accumulation of facts rather than the ability to analyze and discuss problems (Bastid, 1984). Teachers have felt justified in utilizing the traditional rote methods of teacher demonstration followed by student repetition/memorization so that more information can be covered.

By training and experience, through demands upon them from administration, parents, and exam systems, China's teachers may have very restricted conceptions of their responsibility as professionals. This has, no doubt, limited their confidence, preparedness, and ability to attempt any activities other than the most familiar and "safe" teaching routines. In addition, poor leadership within many schools results in low morale, which inhibits resourcefulness and initiative (Dove, 1986). 
TEACHER-STUDENT RELATIONSHIPS

The traditional Confucian master-disciple relationship between teacher and student, as with many aspects of Chinese culture, has all but disappeared in modern China. As discussed earlier, the reasons for this are many. Despite government rhetoric encouraging students and the people to respect teachers, the frustrations of both students and teachers in the current educational system are great, often resulting in strained relationships (Hooper, 1985).

The two-tiered education system is partially to blame for negative student and teacher attitudes. Vocational secondary schools, denounced during the Cultural Revolution, are being revived in an effort to make education more relevant to the country's needs and to diffuse the intense competition for university admission. But these schools are regarded as second-best by both teachers and students, with the result that those assigned to teach and study in the vocational track often lack enthusiasm and discipline (Hooper, 1985).

Students in "ordinary" schools, often find themselves cast aside when not gaining admission to a keypoint school or when not placed in a "quick" or fast class. Hawkins (1982) reports that in many schools, students are divided into three tracks: 30 percent in fast classes, 60 percent in medium, and 10 percent in slow. Students not at the top often show little interest in their studies and tend to become discipline problems. The problems teachers and administrators describe include delinquent and criminal behavior. In an 18-month period in 1981-1982 in Hunan Province alone, over 1,000 incidents of abusing and 
beating teachers were reported to police (Hooper, 1985). A school in Beijing was closed for a month when students pelted stones at teachers' apartments, hospitalizing three (Hooper, 1585). Teachers understandatiy feel they bear the brunt of student dissatisfaction with 1 imited educational opportunity.

Along with discipline problems, truancy and drop out rates are high. Many blame the non-keypoint schools, so starved for funds that they have become known as "Third World" schools (Johnson, 1986). Recently, several municipalities have begun attempting to remedy the imbalance by abolishing keypoint schools at the primary and lower middle school levels (Thogersen, 1987, Johnson, 1986). But even in non-keypoint schools there is competition. The best teachers' time and energy are saved for the fast classes. In some schools, only those who are likely to pass are allowed to take the university entrance exam, thus ensuring the school a better chance to demonstrate its abilities and perhaps become a keypoint school (Hooper, 1985).

Students who manage to stay on the academic track face tremendous pressures in their final years of schooling. One pressure comes from teachers who are anxious to improve their school's university entrance statistics. Both parents and teachers have been described as "merciless" (Hooper, 1985). Stress causes both physical and psychological problems.

Lack of sleep, poor heating, and the general subsistance level diet of much of the Chinese population, cause students of all ages to be susceptible to colds, flu, and hepatitis (Hooper, 1985). Eyestrain caused by dim lighting in schools and homes is another common problem. 
Teacher-student ratio appears favorable in most of China's schools. Primary schools average one teacher for every 25 students, secondary schools average $1: 17$, normal schools average $1: 12$, technical schools average 1: 6, and higher education boasts an average 1:4, probably the lowest in the world (Bastid, 1984). However, the low ratios reflect low teaching loads rather than small classes, rendering the teacher-student ratios meaningless. The average class size in primary and secondary schools (including keypoints) ranges from 35 to 50 students (Bastid, 1984, Collins, 1981, and others). Even in primary schools, teachers specialize in and teach only certain subjects, or one subject, and in only one or two grades (Bastid, 1984). This low utilization is generally the result of inadequate qualifications of teachers, as well as overemployment.

Facilities at primary and secondary schools strain student and teacher relationships. Most schools in China are crowded, lack adequate lighting and heating, and double shifting is common. In a few rural areas classes are still held in caves, cowsheds, and grain storage houses (Li Xing, 1987). Some classrooms lack furniture and most secondary schools have no libraries or laboratories (Bastid, 1984). Classroom equipment is generally limited to a single blackboard and, perhaps, a map. For teachers to meet individually or in small groups with students is almost impossible. After classes, in crowded dormitories or one room apartments shared with family, neither students nor teachers can find an environment for effective study (Bastid, 1984).

The 1985 government-announced goal of nine years of compulsory 
education for all children by the end of the century is thought, by most, to be unrealistic except in urban areas (Johnson, 1986). Government financial efforts and measures directed at improving the training, living, and working conditions of teachers are smoothing the difficulties which hinder educational reform. But despite active propaganda publicizing the correlation between learning and prosperity, local governments and communities are still very reluctant to spend more on education (Bastid, 1984).

\section{EDUCATIONAL RESEARCH IN CHINA}

How teachers view their place in society and their role in educational reform and development is the subject of research in but a few countries, particularly the U.S. While most authorities agree that teachers are the key to improved education, teachers in developing countries are seldom asked to express their views. This has been the case in China. A review of literature about Chinese schooling reveals few studies about teachers and their views, with the exception of those written for "propaganda" or "inspirational" purposes (Li Shuxi, 1981, and Li Xing, 1987).

A review of the long history of education in China, and the role teachers have played, has demonstrated that education has always been highly politicized and closely integrated with the political system in both traditional and modern China. Chinese communist pedagogy has been maintained in a relatively consistent manner since the 1930 s when leaders began to employ such slogans as "education to become both red 
and expert." Political factions have differed on how to put into practice the ideas of socialist education as expressed by Mao and other leaders. The Cultural Revolution saw an emphasis on the "red" side of the debate and as a result educational quality suffered.

Throughout China's modern history, education has been viewed by many of the country's leaders as a "soft" field, lacking in importance compared to more technical fields involving increasing production (Hawkins, 1983). This has been seen most clearly in budget allocations for education which have lagged behind other expenditures, particularly during the years of the Cultural Revolution. Recognizing the seriousness of the problem, government leaders have sought to raise the status of teachers by exhorting the Chinese people to honor teachers. Increased expenditures for education, including raises for teachers, have also been promised (Guo, 1988).

Educational research has not been seen as particularly important for the making of modern educational policy (Cowen and McLean, 1984). A Scientific Research in Education center was established in the early 1960s, but was closed during the Cultural Revolution. It reopened in 1978 and has begun research in several areas, including teaching methods and materials, education theory and history, and school management. Research topics are decided by the Ministry of Education and are policy-related issues. Major teacher universities are also carrying out research. But Chinese authorities "have not yet started trying to solve or publicly discuss the social problems inherent in the current education system" (Thøgersen, 1987).

One Chinese scholar conducting research about teachers, both in 
China and the United States, is Wu Yen-bo (1988), a former instructor at Beijing Teachers College, now a doctoral student at the State University of New York, Buffalo. Mr. Wu interviewed 41 secondary school foreign language teachers, school principals, and government education officials, all in the Beijing area, and found that of 34 teachers, one-fourth had positive feelings about their jobs. About half expressed "outright negative attitudes" about their jobs and another quarter were somewhat neutral in their attitudes, explaining they felt they had no choice but to continue teaching. Mr. Wu identified four areas contributing to negative attitudes from teachers: 1) poor working conditions, 2) low pay, 3) poor academic future, and 4) low social status. Some teachers interviewed mentioned classes with as many 74 students (in beginning foreign language classes), long work days, lack of materials and equipment, and unmotivated students. Others pointed out that they would make three or four times the salary in other jobs if they would be allowed to leave teaching. Many teachers mentioned the difficulty in keeping up their language skills, i.e. the lack of opportunity for continuing education.

At this time the voice of China's teachers remains largely silent. Except for occasional newspaper surveys of teachers regarding issues such as pay or new reform poticies (Guo, 1988, Li, 1988, and others), little is published regarding the beliefs and attitudes of China's teachers. 


\section{HYPOTHESES REGARDING CHINESE TEACHERS AND THEIR BELIEFS}

The central hypothesis which guided this study was that secondary teachers in China hold the view that they have low social status and poor working conditions. The degree to which teachers express dissatisfaction is expected to be influenced by the type of school in which they teach (keypoint teachers expressing less dissatisfaction), the number of years in teaching (older teachers expressing less dissatisfaction, gender (women expressing less dissatisfaction), and subject taught (English, math, and science teachers expressing more dissatisfaction than teachers of other subjects).

Additional hypotheses to be tested include the following: 1) Many teachers believe students are overburdened by schoolwork and the current examination system; the level of agreement will vary with the number of years of teaching, younger teachers expressing a stronger interest in a need for change; 2) The majority of teachers believe they are not adequately prepared to meet the demands of teaching; the degree to which they express agreement will be influenced by years of experience, gender, and years of post-secondary training, with younger female teachers who have no formal college preparation, expressing more agreement; 3) Most teachers believe that the secondary school curriculum should be less "academic" and exam-based and should include sex education, arts education, and student discussions; the extant to which teachers agree will be influenced by years of experience and type of school in which they work, with younger teachers in ordinary schools expressing more agreement. 
In addition to these hypotheses, it was felt to be of interest to identify teacher attitudes in relation to China's socio-political past. In general, it was felt that teachers with experience before the years of the Cultural Revolution (1965-1976) would respond differently than younger teachers. Likewise, teachers with more training, i.e. university preparation, would feel more capable, but, also, less satisfied than teachers with less preparation. 


\title{
CHAPTER III
}

\begin{abstract}
METHOD
This study undertook to investigate the attitudes and beliefs of teachers in contemporary China. While it is known that China has long been identified with valuing education and respecting teachers, the status of the teaching profession and the image of teachers have suffered since 1949. It is generally acknowledged that 1) there is a teacher shortage, 2) many teachers are unqualified, 3) teachers are poorly paid, 4) working conditions are difficult, 5) the curriculum may not be meeting the needs of many students, especially in rural areas, 6) teacher training is insufficient, and 7) the national government has not made edication a priority. While some researchers, both Chinese and foreign, are examining many of these issues, teachers themselves have not been widely heard. In order to add to the body of knowledge concerning contemporary Chinese education, this investigation of teachers' attitudes and beliefs was undertaken.
\end{abstract}

\section{SUBJECTS}

The study was 1 imited to secondary teachers because of their similarity in preparation (i.e., one to four years of postsecondary education) with secondary teachers in other nations. Future comparative studies may be more feasible as a result. Chinese primary teachers 
generally have a secondary education, at best, which may limit future comparability.

Sixty secondary teachers participated in the study, 22 males (37\%) and 38 females (63\%). They ranged in age from 20 to 62 , with a mean age of 34. To enable age to be used as a grouping variable, subjects were divided into three approximately equal groups: younger teachers (under age 30), "mid-age" teachers (ages 30 to 40), and "older" teachers (over age 40). The classification of teachers into these three age groups has the additional advantage of reflecting generational differences, representing experiences in socio-political change.

Forty subjects (67\%) reported having no college degree, while twenty (33\%) reported having a Bachelor of Arts Degree. Almost half the group (47\%) reported attending Beijing Teachers College, 10\% attended Beijing Normal University, 7\% attended Beijing Pedagogical Institute, and 3\% attended Mid-China Normal University. Approximately 34\% of the subjects reported no college preparation, but, rather, attended secondary schools, normal schools or other types of schools.

Forty-three subjects (72\%) reported teaching in urban schools and 17 (28\%) in suburban schools. (Beijing is a municipality of about nine million people, with the "old city" and the suburbs generally undistinguishible). Twenty-four subjects (40\%) reported teaching in "keypoint" schools, while $36(60 \%)$ taught in "ordinary" schools. Years of teaching experience ranged from one year to 32 years, with a mean of 9 years. In order to employ years of teaching as an independent grouping variable, three approximately equal groups were formed: those 
with four years or less of teaching experience, those with five to twelve years, and those with over 12 years experience.

Eighteen respondents (30\%) indicated that they taught science (chemistry, biology, or physics) or math subjects. Nineteen (32\%) taught English. The remaining 38\% of the respondents taught social sciences (history, geography, or political science), music, or Chinese (1anguage/literature). This group of subjects was combined to form a category labeled "liberal arts." Thus, subjects taught were clustered into three approximately equal groups to enable their use as variables.

\section{QUESTIONNAIRE}

A review of teacher belief/attitude scales developed in the United States (Hal1, 1974; Fimian, 1984; Chase, 1985; Sylvia and Hutchinson, 1985; Abelson, 1986; and others) revealed that such scales typically contain approximately 40 to 70 items, generally clustering into five to ten subscales. Typical subscales included areas such as stressors, work conditions, student discipline/management, status, career satisfaction, and administration/supervision. No teacher attitude scales were located which had been prepared for use in developing countries. In addition, literature regarding research surveys or other means of ascertaining teacher opinion in China were not located.

A review of current issues mentioned frequently in the Chinese education literature provided a number of probable areas of concern to secondary teachers. These areas were initially titled as follows:

1) status, 2) student discipline, 3) work conditions, 4) teacher 
preparation, 5) career satisfaction, 6) educational policy, 7) teaching philosophy, and 8) role/responsibility. Sixty statements were developed.

Respondents were asked to rate, on a six-point scale, the degree of accuracy to which they agreed or disagreed with a statement, a rating of "one" indicating "extremely inaccurate" and a rating of "six" indicating "extremely accurate." (Please refer to appendices A and B).

Personal data requested included sex, age, subjects' years of education, name of higher education institute attended, years of teaching experience, subject(s) currently taught, type of school where currently teaching (keypoint or ordinary), and location of school (urban or suburban).

The questionniare was translated into Chinese by Mr. Li Wei, Instructor in the English Department of Beijing Teachers College. Mr. Li holds an M.S. degree from the State University of New York, Cortland, and is an experienced interpretor and translator in the field of teacher education.

\section{PROCEDURE}

Questionnaires were accompanied by a letter (please refer to Appendices C and D) explaining the purpose of the study (i.e., to explore the views of teachers). Responses were anonymous to insure subjects' honest and candid responses. Participants were invited to add comments on a separate piece of paper. The letter was signed by $\mathrm{Mr}$. Li (translator) rather than the principal investigator, to avoid possible 
response bias which may be associated with a foreign researcher. $\mathrm{Mr}$. Li received the completed responses at his home address. A stamped, addressed envelope was provided to improve response return. One hundred-twenty five questionniares were distributed and 60 were completed and returned, a response rate of $48 \%$.

Teachers in the Beijing area who attended Beijing Teachers College inservice training classes were asked to distribute the questionnaires to colleagues in their various schools. While the Beijing area is not representative of China, the study was conducted there because of the relative ease with which contacts were made through the college, host to the Oregon Teacher Education Program in China in 1986 and 1987. 


\title{
CHAPTER IV
}

\begin{abstract}
RESULTS
This study was initiated in an effort to investigate the perceptions of secondary school teachers in China. The initial section of this chapter is designed to, first, describe the subject population according to demographic characteristics. Secondly, global response patterns to the teacher questionnaire will be reported in order to index the teachers' general endorsement concerning issues such as educational philosophy and policy, teacher preparation, job satisfaction, social status, and student discipline. The final component in this initial section will present results of analyses of differences between the questionnaire items and the demographic variables. The second section of this chapter sets out to employ a procedure for determining distinct teacher-response patterns to the questionnaire items. The goal in classifying individuals according to their specific response patterns is to more clearly differentiate teacher attitudes and perceptions.
\end{abstract}

\section{DEMOGRAPHIC CHARACTERISTICS OF STUDY SAMPLE}

The teachers participating in the study reported an average of nine years of teaching experience $(S D=9.1)$, with a range of one to 32 years. Urban school teachers comprised $72 \%$ of the sample, and suburban schools, 28\%. Of the 60 teachers, 40\% taught in "keypoint" (key) 
schools, 28\%. Of the 60 teachers, $40 \%$ taught in "keypoint" (key) schools and 60\% in "ordinary" schools. Surprisingly, $33 \%$ of the teachers reported having a Bachelor's Degree, while 67\% did not. (The Chinese Ministry of Education has defined "qualified" upper secondary teachers as having four-year college degrees and has reported, in 1980 , that $50 \%$ of China's upper secondary school teachers were qual ified.) Twenty-seven percent of the respondents reported teaching science or math, 37\% taught liberal arts (history, geography, music, and Chinese literature/language), and $32 \%$ taught English.

The interrelationship among the independent variables indicated that male teachers were significantly more likely to have Bachelor's Degrees than female teachers $\left(X^{2}(3, \underline{N}=60)=4.34, p<.05\right)$. While half the males reported having degrees, only a quarter of the females reported degrees. It was also discovered that the female teachers were more likely to be teaching in urban schools (72\%), while males (59\%) were more highly represented in suburban schools $\left(\chi^{2}(3, \underline{N}=60)=5.01\right.$, $\mathrm{p}<.05)$.

Individuals with Bachelor's Degrees further distinguished themselves both in terms of age $\left(\chi^{2}(5, \underline{N}=60)=15.97, p<.01\right)$ and by subject taught $\left(X^{2}(5, \underline{N}=60)=6.27, p<.05\right)$. Younger teachers (under 30 years of age) were almost three times as likely (70\% versus $25 \%$ ) to have degrees as the "mid-age" group (30 to 40 years of age). Only $5 \%$ of the teachers over 40 years of age had Bachelor's Degrees. While $45 \%$ of those teaching science/math and $40 \%$ teaching 1 iberal arts subjects had Bachelor's Degrees, only 15\% of those teaching English had obtained a Bachelor's Degree. 


\section{DESCRIPTION OF QUESTIONNAIRE RESPONSES}

The goal of this section is to provide a descriptive account of the teachers' responses to the questionnaire items. Items reported in this section were those whose means were either low, representing strong disagreement, or high, representing strong agreement. Questionnaire items with which teachers expressed most dissatisfaction represented the areas of social status, work conditions, and psychological functioning. Alternatively, those items receiving the highest satisfaction or endorsement represented domains of student and social welfare, the role of discipline, and curriculum policy.

Teachers perceive themselves as having poor social status and indicated that their families are not proud of them in their professional roles as teachers. Pay was perceived as not being adequate, nor was there a feeling that there were opportunities for advancement in the field of education. Work conditions were described as limiting; specifically, there were neither sufficient resources available, nor adequate administrator support given to assist teachers.

The results gave a clear indication as to motivational interests in being a teacher. Individuals reported a strong belief that teachers should work for the social good of society, rather than for themselves. Similarly, teachers expressed a high interest in helping students learn. There was also a pattern of responses reflecting a "progressive" belief that students should be taught to think, rather than to memorize facts, that the process of learning is more important than the product, that students should be given more freedom to speak their minds, and 
that the arts should be included in the school curriculum.

Interestingly, this sample of teachers embraced a more traditional view of discipline, endorsing items reflecting the need for a firm approach to classroom management. The demands of teaching were reflected in the reporting of a high degree of stress and detrimental effects on their general health.

Finally, teachers reported distinct attitudes regarding educational policy. In general, teachers believe that the government does not adequately support the education system, including sufficient teacher preparation at colleges and universities. Teachers believe that college-bound secondary students are favored over other students and that minority students should have special attention within the education system.

\section{DEMOGRAPHIC DIFFERENCES BY TEACHER BELIEFS}

The results of a one-way analysis of variance indicate that male teachers perceive their families as being less proud of their being teachers than do the families of female teachers $(E(1,58)=9.93$ $\mathrm{p}<.01)$. Male teachers reported a stronger belief in physical punishment in school $(E(1,58)=4.74, \mathrm{Q}<.05)$, but also felt that students should have greater freedom to speak openty in class $(\underline{E}(1,58)=5.74, \underline{\mathrm{p}}<.01)$. When gender is further divided according to whether or not a Bachelor's degree was obtained, additional differences emerged. Male teachers without college degrees were significantly more likely $(E(1,56)=4.53$, $\mathrm{p}<.05)$ to disagree with a need for sex education classes, while female 
teachers without degrees were the strongest proponents of the need for sex education. As was expected, non-degree male teachers reported that observing other teachers was significantly helpful to their teaching $(\underline{F}(1,56)=4.20, \underline{p}<.05)$ and that past teachers were significantiy more likely to have influenced them $(E(1,56)=4.32, \mathrm{p}<.05)$. Alternatively, males with degrees reported the least benefit in observation and previous teacher influence. Interestingly, male and female teachers without degrees expressed a stonger $(\underline{F}(1,57)=3.92, \underline{\mathrm{p}}<.05)$ belief in special attention for minority students than male teachers with degrees.

Two main effects for degree indicate a more conservative perspective towards discipline for those teachers without degrees. Specifically, teachers without degrees indicated a stronger belief that parents, rather than teachers, were responsible for moral values attainment $(E(1,56)=4.74, \underline{p}<.05)$. Similarly, they endorsed the need to be firm and consistent as a critical component in their instruction of students $(\underline{E}(1,57)=6.64, \mathrm{p}<.01)$. The only other remaining difference, based on the holding of a degree, is that individuals without a degree indicated that there are inadequate resources available to them in their schools to assist them in instruction.

The results of the analyses of variance addressing age group differences, revealed that "older" teachers (over 40 years of age), endorsed the need for discipline more strongly. Specifically, they reported a stronger need to take an active role in disciplining students $(\underline{F}(2,59)=5.68, \underline{p}<.01$ ) and, along with their "mid-aged" (30 to 40 years of age) counterparts, indicated a need to be firm and consistent with students $(E(2,59)=8.64<.001)$. 01der teachers also perceived the 
responsibility for moral education to fall on the shoulders of parents, rather than teachers $(E(2,59)=4.11 \mathrm{p}<.05)$. Unexpected 7 , it was the older teachers, rather than the younger teachers, who endorsed the belief that tenure protects incompetent teachers $(\underline{F}(2,58)=5.37$ $\mathrm{p}<.01)$. Finally, and not surprisingly, younger teachers expressed the belief that younger teachers, in general, are more capable than older teachers $(\underline{F}(2,59)=6.90 \underline{p}<.01)$.

As might be expected, similar patterns to age differences resulted when years of teaching experience were analyzed. Teachers with over 12 years of experience were more likely to believe that permissive parenting was more likely the cause of behavior problems in school $(E(2,58)=4.43 \underline{p}<.05)$; reported the need for teachers to take a more active role in discipline $(\underline{F}(2,59)=5.22 \mathrm{p}<.01)$; and should be firm and consistent in order to be effective teachers $(E(2,59)=3.82$ $\mathrm{p}<.05)$. These older teachers also expressed less sympathy for the heavy academic load that most secondary students carry $(E(2,53)=3.97$ $\mathrm{p}<.05)$. While teachers with the least experience (4 years and under) reported significantly greater dissatisfaction with the pay they receive $(\underline{D}(2,59)=5.19 \mathrm{P}<.01)$, they were least likely to criticize the tenure system as protecting incompetent teachers $(\underline{E}(2,58)=4.74 \underline{p}<.01)$. Similar to the age difference findings, teachers with the least amount of experience reported that younger teachers are more capable than older teachers $(\underline{F}(2,59)=8.89 \underline{p}<.001)$.

When results were analyzed according to the subject matter taught, very different patterns of results emerged. The results of the analyses 
of variance indicated that teachers of 1 iberal arts subjects perceived themselves as being significantly better prepared than teachers of other subjects $(E(2,55)=3.87 \mathrm{p}<.05)$; as being more concerned about the effects their teaching has on their students' 1 ives $(\underline{F}(2,56)=4.04$ p<.05); and expressed a greater feeling of commitment toward teaching $(\underline{E}(2,55)=4.30 \mathrm{p}<.05)$. Science and math teachers reported significantly greater dissatisfaction toward being teachers $(E(2,55)=$ $3.35 \mathrm{p}<.05)$. They also acknowledged that they feel their families are less proud of them for being teachers than was true for teachers of other subjects $(E(2,55)=4.91 \mathrm{p}<.01)$. This pattern of dissatisfaction was further displayed by science and math teachers through their reporting that their schools' reputations for teacher quality were not high $(E(2,56)=4.32 \mathrm{~g}<.05)$.

Results from a two-way (key school/ordinary school by urban/suburban) analyses of variance indicated that while urban key school teachers expressed insufficient administrative support, suburban key school and ordinary school teachers perceived adequate support $(E(3,59)=5.94 \underline{\mathrm{g}}<.001)$. In spite of this result, the same urban key school teachers reported significantly less stress $(\underline{F}(3,58)=2.65$ $\mathrm{p}<.05)$ than their suburban ordinary school counterparts who reported the most stress of all teachers. Those teachers who reported the least support from administrators, likewise, indicated the least amount of stress. Conversely, those reporting the greatest administrative support also reported the highest levels of job-related stress.

Further analyses of variance results reflect a generally mixed progressive and conservative profile of attitudes held by key and 
ordinary school teachers toward education. A significant interaction resulted from a two-way analysis of variance, showing that while no key school teachers strongly agreed that teaching thinking skills is more important than teaching facts $(E(3,58)=2.76 \underline{p}<.05)$, key school teachers were less likely to report that student interaction inhibits Tearning $(\underline{F}(1,59)=4.23 \underline{\mathrm{g}}<.05)$.

Additional findings show that suburban key school teachers viewed the reputation of their school's students as significantly greater than urban key school or ordinary school teachers $(E(3,59)=7.90 \mathrm{p}<.001)$. Finally, suburban key school teachers reported a significantly stronger belief, than their urban key school counterparts, that people should work for the good of society, more than for themselves $(E(3,59)=2.83$ $\mathrm{p}<.05)$. There were no differences between ordinary school urban and suburban school teachers pertaining to this belief.

\section{A BELIEF TYPOLOGY BASED ON CLUSTER ANALYSIS}

In an effort to empirically classify teachers according to their beliefs and attitudes toward education, including perceptions involving curriculum and policy, student discipline, status, and work conditions,

a cluster analysis was performed. Clustering solutions were derived for two-, three-, and four-level groups. The results reported below will describe the three-group solution, as it was, by far, the most interpretable. It should be noted that the ten variables from the Teacher Questionnaire possessing standard deviations of less than one were excluded as discriminating variables. Eliminating these variables 
had the effect of both providing a more adequate variable-to-subject ratio, and dropping variables that were least likely to differentiate among individuals. The procedure used in determining the number of grouping clusters was based on maximizing the number of groups, without minimizing interpretability, and maintaining adequate cluster membership. The method used for combining clusters was based on Ward's method, which is designed to optimize the minimum variance within clusters, executed through SPSS.

Given these resultant groups, a discriminant function analysis was computed to evaluate the overall ability of these variables to differentiate between them. The results of this discriminant function analysis, based upon a direct method of variable entry, indicate-an overall main effect, $E(2,57)=232.55 \mathrm{Q}<.001$. The test for homogeneity of variance was nonsignificant, indicating that conditions required for the inclusion of this analysis had been met. The derived canonical coefficient generated by the discriminant analysis was .977 . The resulting discriminant functions were able to classify all teachers into their respective cluster groups.

Given the overall significance of the multivariate F-test in the discriminate analysis, univariate analyses of variance could be, and were, computed on each of the Teacher Questionnaire items. Tukey post-hoc comparisons were calculated to further test the differences among groups. As can be seen from Table II, individuals in Group One distinguished themselves as being the least satisfied of all the teachers, while individuals in Group Three were the most satisfied. 
TABLE II

\begin{abstract}
ANALYSIS OF VARIANCE VARIABLES WHICH MAXIMIZE DISCRIMINATION AMONG CLUSTER GROUPS
\end{abstract}

\begin{tabular}{|c|c|c|c|c|}
\hline \multicolumn{2}{|c|}{$\begin{array}{l}\text { ITEM } \\
\text { CLUSTER } \\
\text { NUMBER } \\
\text { DIFFERENCES }\end{array}$} & RATIO & SIGNIFICANCE & GROUP \\
\hline $\begin{array}{l}3 \\
4\end{array}$ & $\begin{array}{l}\text { Closest friends are teachers } \\
\text { Pay is fair for my ed/train }\end{array}$ & $\begin{array}{l}3.708 \\
3.122\end{array}$ & $\begin{array}{l}.03 \\
.05\end{array}$ & $\begin{array}{l}3>1 \\
3>1\end{array}$ \\
\hline $\begin{array}{r}8 \\
10\end{array}$ & $\begin{array}{l}\text { Studts respon for thr learning } \\
\text { Adminstr is helpful/supportive }\end{array}$ & $\begin{array}{l}3.702 \\
9.051\end{array}$ & $\begin{array}{l}.03 \\
.0004\end{array}$ & $\begin{array}{l}1>3 \\
3>1\end{array}$ \\
\hline $\begin{array}{l}11 \\
12\end{array}$ & $\begin{array}{l}\text { Vacation is import benefit } \\
\text { I have good social status }\end{array}$ & $\begin{array}{l}7.156 \\
12.09\end{array}$ & $\begin{array}{l}.002 \\
.0001\end{array}$ & $\begin{aligned} 2, & >1 \\
3 & >1,2\end{aligned}$ \\
\hline $\begin{array}{l}14 \\
17\end{array}$ & $\begin{array}{l}\text { Adequate resources for tchng } \\
\text { Nat'1 govt supports education }\end{array}$ & $\begin{array}{l}3.586 \\
17.08\end{array}$ & $\begin{array}{l}.03 \\
.0001\end{array}$ & $\begin{array}{l}3>1 \\
3>1,2\end{array}$ \\
\hline $\begin{array}{l}20 \\
21\end{array}$ & $\begin{array}{l}\text { Sex ed should be taught } \\
\text { More pay, more satis as tchr }\end{array}$ & $\begin{array}{l}4.078 \\
7.838\end{array}$ & $\begin{array}{l}.02 \\
.001\end{array}$ & $\begin{array}{l}1>2,3 \\
3>1,2\end{array}$ \\
\hline $\begin{array}{l}22 \\
24\end{array}$ & $\begin{array}{l}\text { I exp much stress in teaching } \\
\text { Fam is proud of me being tchr }\end{array}$ & $\begin{array}{l}8.734 \\
8.629\end{array}$ & $\begin{array}{l}.0005 \\
.0005\end{array}$ & $\begin{aligned} 2, & >1 \\
3 & >1,2\end{aligned}$ \\
\hline $\begin{array}{l}26 \\
29\end{array}$ & $\begin{array}{l}\text { I make a diff in studts lives } \\
\text { Observing other tchrs/helpful }\end{array}$ & $\begin{array}{l}4.550 \\
16.18\end{array}$ & $\begin{array}{l}.01 \\
.0001\end{array}$ & $\begin{array}{l}1,3>2 \\
2,3>1\end{array}$ \\
\hline $\begin{array}{l}30 \\
31\end{array}$ & $\begin{array}{l}\text { I'm dissatis being a teacher } \\
\text { Past tchrs have posit infl me }\end{array}$ & $\begin{array}{r}21.82 \\
7.305\end{array}$ & $\begin{array}{l}.0001 \\
.002\end{array}$ & $\begin{array}{l}1,2>3 \\
2,3>1\end{array}$ \\
\hline $\begin{array}{l}33 \\
37\end{array}$ & $\begin{array}{l}\text { Teaching is challenging } \\
\text { I feel committed to teaching }\end{array}$ & $\begin{array}{l}5.259 \\
23.49\end{array}$ & $\begin{array}{l}.008 \\
.0001\end{array}$ & $\begin{aligned} 2, & >1 \\
3 & >1,2\end{aligned}$ \\
\hline $\begin{array}{l}42 \\
43\end{array}$ & $\begin{array}{l}\text { Studt quality good at my schl } \\
\text { Tchr should actively discipl }\end{array}$ & $\begin{array}{l}7.160 \\
20.77\end{array}$ & $\begin{array}{l}.002 \\
.0001\end{array}$ & $2, \begin{array}{l}3>1 \\
3>1\end{array}$ \\
\hline $\begin{array}{l}45 \\
47\end{array}$ & $\begin{array}{l}\text { Tchr quality good at my school } \\
\text { Import to be firm/consistent }\end{array}$ & $\begin{array}{l}5.400 \\
11.72\end{array}$ & $\begin{array}{l}.007 \\
.0001\end{array}$ & $2, \begin{array}{l}3>1 \\
3>1\end{array}$ \\
\hline $\begin{array}{l}50 \\
54\end{array}$ & $\begin{array}{l}\text { Minority studt/special attent } \\
\text { Younger tchrs more capable }\end{array}$ & $\begin{array}{l}12.10 \\
8.613\end{array}$ & $\begin{array}{l}.0001 \\
.0005\end{array}$ & $\begin{aligned} 2, & 3>1 \\
1 & >2,3\end{aligned}$ \\
\hline 56 & I envy other tchrs who leave & 12.77 & .0001 & $1,2>3$ \\
\hline
\end{tabular}


Furthermore, Group One teachers reported that they were envious of those individuals able to leave the teaching profession. These Group One individuals expressed a feeling of low social status and an absence of family pride toward their teaching profession. In spite of this, they were "progressive" in their thinking in that they were the strongest proponents of sex education in the schools and felt that they made a difference in the lives of the students they taught. Interestingly, these teachers reported that they experienced far less stress than teachers in the other two groups. They also noted that observing other teachers was less helpful to them in their professional development. These last two findings are clarified by the fact that teachers in this group are more likely to have graduated from a university, i.e. have teacher preparation, than teachers in the other two groups.

Teachers constituting the second group distinguished themselves as much more apathetic than Group One and Group Three teachers, stating the self-perception that they, as teachers, did not make much difference in their students' lives. It is not surprising, therefore, that Group Two teachers report more stress, find teaching more challenging, are generally dissatisfied with being a teacher, and envythose who have left the field. Group Two teachers also advocate that teachers take a more active role in disciplining their students, being more firm and consistent in their teaching roles.

The most note-worthy distinctions which identify members of Group Three are their feelings of positive social status, family pride, and commitment toward the teaching profession. These individuals were 
considerably more positive in their general attitudes toward teaching and the field of education. They report that their closest friends are teachers, that they find support from school administrators, and perceive that resources necessary for instruction are adequate. Similarly, they describe their schools as having good reputations, both for the quality of teachers and the students. Like members of Group One, they see their teaching roles as making a difference in students' lives. Although they perceive the pay as being fair for their levels of training and experience, they, nevertheless, report that they would be more satisfied with higher pay. Like members of Group Two, teachers in Group Three support a more active discipline role. Interestingly, while they are supportive of special attention for minority students, they express a "conservative" view toward sex education in the schools, indicating less interest in this curriculum addition.

The demographic variables which differentiated among these three groups of teachers, were age, years teaching experience, and college degree. (Please see Table III). While an overwhelming $70 \%$ of Group One teachers graduated from a university with a Bachelor's Degree, only $21 \%$ of Group Two and 28\% of Group Three had obtained college degrees. Group One teachers also had significantly fewer years of teaching experience (four years) compared to either Group Two (13 years) and Group Three (12 years). Not surprisingly, the same pattern emerged for age, with Group One teachers being significantly younger $(H=28$ years) compared to Group Two teachers $(M=37$ years) or Group Three $(M=35$ years). No other demographic variables differentiated these three groups. 
TABLE III

TEACHER BELIEFS BASED ON CLUSTER ANALYSIS

GROUP ONE TEACHERS:

DEMOGRAPHICS

70\% have B.S. Degree mean of 4 years teaching mean age of 28 years

GROUP TWO TEACHERS:

DEMOGRAPHICS

$21 \%$ have B.S. Degrees mean of 13 years teaching mean age of 37 years

GROUP THREE TEACHERS:

\section{DEMOGRAPHICS}

$28 \%$ have B.S. Degrees mean of 12 years teaching mean age of 13 years
BELIEFS

least satisfied as teachers envious of teachers who leave profession poor social status lack of family pride in their teaching do make a difference in students' lives experience least stress sex education should be taught

\section{BELIEFS}

do not make difference in students' lives dissatisifed as teachers find much stress in teaching find teaching challenging envious of teachers who leave profession should take active role in discipline being firm/consistent is critical

\section{BELIEFS}

do make a difference in students' lives most satisfied as teachers would be happier with higher pay pay is fair for experience and education most positive with social status families have pride in them as teachers closest friends are teachers committed to teaching find administrators supportive find school resources adequate their schools have good reputations for quality of students and teachers should take active role in disciplining minority students should receive appropriate education sex education should not be taught 


\section{CHAPTER V}

\section{DISCUSSION}

The goal of this study was to explore teacher beliefs regarding the teaching profession in modern China, as well as general attitudes and perceptions in such areas as educational philosophy and policy, student discipline, curriculum, teacher preparation, social status, and job satisfaction. A Teacher Questionnaire was developed and distributed to secondary teachers in the Beijing area. The general picture that emerged was one of dissatisfaction with the current status of the teaching profession in China. Areas of greatest concern to teachers included the pay, teaching resources within the schools, school administrator support, and opportunities for advancement. In addition, teacher training was considered insufficient, as well as government support for education. Teachers reported a high degree of stress and poor health.

Major findings which emerged included the belief by teachers that students should be taught to think, rather than memorize facts, and that the process of learning is more important than the product. They also felt that schools favor the college-bound students, rather than those who will join the work force after school. Teachers endorsed the notion of students speaking their minds in the classroom. 
These results confirm recent media reports of widespread discontent among China's teachers. They also suggest that teachers have a desire to see the traditional teaching methods modified to permit more student participation and freedom of expression.

Finally, the results are seen to make some contribution to furthering the understanding of differences in teacher beliefs and perceptions within the profession. These results revealed meaningful differences between male and female teachers, younger versus older teachers, and teachers with degrees and those without degrees. There were also interesting variations among those teaching different subjects.

In the pages that follow, results will be be discussed with relevance to the range of opinion expressed by a group of teachers. Attention will then be turned to a final discussion of some of the perceived limitations of the present study and an exploration of the relevance of these findings as a guide to future research.

\section{SUMMARY}

As discussed in Chapters I and II, previous research into the beliefs and perceptions of teachers in China has been limited. A review of the literature has revealed a lack of systematic inquiry into the state of the teaching profession by national and provincial educational research bureaus, as well as the research institutes associated with various teachers' colleges and universities. In addition, foreign researchers have not dealt directly with topics related to the teaching 
profession. This study, while limited to one geographical location within China, has revealed that teachers have some very distinct perceptions of their profession and a willingness to share these views. It is clear from this study that teachers consistently perceive themselves as having poor social status. They feel strongly that the government does not adequately suppport the education system and that salaries, as well as teaching resources within the schools, are inadequate. Teachers, particularly the males, revealed the perception that their families were not proud of their being teachers. Teachers in this study also reported a high degree of stress and declining health. Thus, the central hypothesis guiding this study, i.e. that teachers feel they have poor social status and poor working conditions, is confirmed. Teacher preparation (specifically, education, psychology, and teaching methodology courses) was perceived as insufficient by the teachers participating in this study, confirming an additional hypothesis. As was discussed earlier, teachers' colleges devote most of their curriculum to coursework in the major areas of study, citing the need for subject area competence before pedagogy.

The Chinese Ministry of Education has defined "qualified" secondary school teachers as having completed a two-year preparation program (for lower secondary school teachers) or a four-year program (for upper secondary teachers), although the content of preparation programs is not defined. In 1980, official figures show that about half of China's upper secondary teachers have the suggested preparation. (See Table I). It might be assumed that in the capital city the percentage of qualified teachers is higher than in rural areas. 
However, this study suggests that the overall actual percentage of qualified teachers, regardless of geographic location, is, most likely, lower than official figures report. Only a third of the teachers reported having Bachelor's degrees, while another third reported having attended courses at various teachers' colleges. The extent of the non-degreed teachers' preparation is unclear. Years of education were reported as 12,14 , or 16 years. China has experimented with a variety of grade configurations since 1949, so that 12 years of education may represent 10 years of primary and secondary schooling, followed by 2 years of post-secondary schooling. On the other hand, it may also represent 12 years of primary and secondary schooling, with no post-secondary preparation. Likewise, 16 years of education may include several years of "nonformal" self-study (television or correspondence courses) or evening and summer inservice classes on a parttime basis. Regardless of how these data are portrayed, it is quite evident that Chinese secondary school teachers, for the most part, do not have the formal education necessary to prepare them for the societal demands of educating the current school-age generation and preparing them for the twenty-first century.

When the aspect of possessing a degree was further evaluated, it was found, as was expected, that male teachers were twice as likely to hold degrees than female teachers, supporting the previous literature that females are underrepresented in both secondary and higher education. It is difficult to interpret the complete significance of this finding, as it could be the consequence of a self-selection bias, family selection bias (parents deemphasizing education for daughters), 
or a socio-cultural bias. Regardless of one's orientation, the fact remains that a substantial gender gap exists which requires serious attention.

Surprisingly, keypoint school teachers, generally regarded as the best trained, did not hold significantly more degrees than ordinary school teachers (55\% versus $45 \%$ ). However, one can see the effects of China's increasing higher education opportunities in the number of younger teachers (under age 30) holding college degrees. Teachers under 30 were three times as likely to hold degrees as those between 30 and 40 years of age ( $75 \%$ versus $25 \%$ ), while only $5 \%$ of those over 40 held degrees. In addition to the limited higher education opportunities for the older generation of teachers, the Cultural Revolution denied access to education for most Chinese. Another explanation for this dramatic trend is that older teachers with degrees left the profession during the time of the Cultural Revolution and did not return.

Teachers with degrees, similarly, differed in education according to the subjects they taught. Forty-five percent of those teaching science/math subjects and $40 \%$ of those teaching "1iberal arts" subjects (social sciences, music, and Chinese language/literature) held college degrees, while only $15 \%$ of the English teachers held degrees. This suggests that foreign language teachers (i.e., English teachers) received the majority of their training through other means. It may also simply be an index of the high demand for competent English teachers in the market/economy, such that English teachers with the best preparation, and, perhaps, greatest fluency, are in demand in other sectors of Chinese society, i.e., publishing, government, business, 
college teaching, tourism, foreign trade, etc.

Age and years of teaching experience were found to influence teacher perceptions in several areas. Teachers over 40 years of age, as well as those with over 12 years of teaching experience, perceived a strong belief in the need to take an active role in the discipline of students, feeling that being firm and consistent is essential to good education. The more experienced teachers also felt that permissive parenting was a likely cause of behavior problems at school and expressed little agreement that students carry too heavy an academic load.

In a value-consistent manner, teachers over 40 expressed strong agreement that tenure protects incompetent teachers. Younger teachers did not perceive tenure as a major concern, although they did feel that younger teachers were more capable than older teachers. Younger teachers, with under five years of teaching experience, expressed the most dissatisfaction with pay, as noted. These younger teachers were also more highly educated. Thus, it is difficult to determine whether their beliefs about education reflect values acquired at university, indicate an experience discrepency, or more clearly represent a generational shift.

Subject area taught was found to influence teacher perception regarding commitment to teaching and concern about teachers' effects upon students, with teachers of liberal arts subjects expressing the most positive responses. In addition, this group of teachers perceived themselves as being well-prepared for teaching. Teachers of science and math subjects reported the greatest dissatisfaction with being teachers, 
acknowledging their families' lack of pride in their careers and reporting that their schools' reputations for teacher quality were not high. With China's Four Modernizations valuing math and science skills, individuals teaching these subjects, no doubt, yearn for technical positions outside of teaching, with higher status, better pay, and better work conditions.

With keypoint schools touted as the best-equipped and best-staffed schools in the country, and with the most able students, it was not surprising to find that the teachers in urban keypoint schools reported experiencing the least job-related stress. Interestingly, however, this group of teachers also perceived their school administrators as the least helpful and supportive. This is a possible reaction to administrators holding teachers accountable for their students' examination performances and/or the lack of training and skill of many school administrators in China.

Conversely, suburban ordinary school teachers reported the most job-related stress of all teachers, yet found administrator support adequate. Both urban and suburban keypoint teachers held a surprisingly traditional view regarding teaching methodology in that they did not advocate that teaching thinking skills should be stressed over teaching facts, reflecting, perhaps, their job roles of preparing students for the university examinations. Suburban keypoint school teachers viewed the quality of their schools' students as significantly higher than ordinary school teachers did and, surprisingly, higher than urban keypoint teachers did.

Secondary teachers in China are not a homogeneous group in their 
perceptions of the education system and the teaching profession, in spite of general agreement in many areas. The overall picture which emerged from this study was that there are significant differences in teachers' perceptions. Findings suggest that the youngest, least experienced teachers (an average of 28 years of age with four years of teaching experience), who are also, generally, those teachers most likely to hold college degrees ( $70 \%$ of this group), perceive most strongly the low social status of the teaching profession and the lack of family pride in their roles as teachers. Perhaps as an effect of their preparation and/or youth, they also report less job-related stress. These young teachers were also likely to advocate the need for sex education in the curriculum and to feel they made a difference in the lives of their students. These views may be interpretable as teachers identifying with the needs of young people.

01der teachers, with more years of teaching experience (12 to 13 years, on the average) and a smaller likelihood of a college degree (21\% to $28 \%$ ), fell into two distinct groups. One group reported finding teaching unsatisfying, challenging, and stressfut. These teachers advocated the view that they did not feel they made much difference in their students' lives and that they felt envious when they saw fellow-teachers leaving the field for other jobs. In addition, this group was stronger in its support for the importance of discipline.

Conversely, the other group of more senior teachers reported feelings of positive social status, family pride in their profession, and a commitment toward the teaching profession. These teachers perceived the pay as being fair for their levels of training and 
experience, though they also reported that they would feel more satisfied with higher pay. Thisgroup acknowledged that their closest friends were teachers, that they find their school administrators helpful and supportive, and that they find the resources in their schools are adequate for their teaching. These teachers felt that they made a difference in the lives of their students. They perceived their own schools as having good reputations for the quality of both teachers and students. These more experienced teachers also supported an active teacher role in discipline and special attention to the education of minority students. However, they were not particularly supportive of the notion of sex education in the schools. These beliefs suggest that there are teachers, characterized, perhaps, as more traditional and committed in their outlooks, who find teaching conditions less dissatisfying than many of their colleagues.

In addition to completing the questionnaire, several teachers accepted the request to add personal comments. One respondent, a teacher for several decades, was critical of the inadequate support given teachers by education officials at the district, municipal, provincial, and national levels. This teacher lamented the lack of a realistic long-range education policy and the low priority given education, calling the current situation "a crisis." Other problems were mentioned, including teachers who teach only their speciality subjects, neglecting other educational responsibilities as well as the students.

Another respondent, a young teacher, mourned the lack of opportunity for advancement and availability of continuing education for 
teachers. This teacher also experienced frustration over the limited provisions for intellectual exchange among colleagues and the dampening of the "spririts" of young teachers. As was expected, all teachers cited the poor pay and benefits for teachers. One teacher described the humiliation of seeing "lower secondary school students with a bit of vocational training"receiving a higher salary than a teacher with a college degree. The frustrations expressed by these teachers support the findings of Wu (1988), who interviewed over 30 secondary teachers and found wide dissatisfaction with the status of the profession, and serve as further confirmation of the validity of the questionnaire results.

\section{CONCLUSIONS}

The teachers participating in this study were found to view themselves as having low social status and poor working conditions. Teachers' responses to questionnaire items dealing with these issues revealed perceptions of lack of family pride in them because of their profession, poor pay, job-related stress, poorer health, inadequate resources for teaching, lack of opportunity for advancement, and unsupportive adminstrators. They also viewed the government as inadequate in its support and felt that teacher training is insufficient.

The degree to which teachers expressed dissatisfaction was found, as hypothesized, to be partially influenced by gender, with male teachers expressing more concern for the lack of family pride, 
suggesting sex role stereotyping, both familial and cultural. Likewise, the number of years of teaching experience influerced perceptions, with less experienced (younger) teachers reporting greater dissatisfaction with the pay they receive than older teachers. This may be more an effect of the likelihood these younger teachers also hold highly-valued college degrees (have better preparation) and have expressed they feel more capable than older teachers.

As hypothesized, individuals teaching different subjects responded different1y, with science and math teachers reporting the greatest dissatisfaction and lack of family pride when compared with teachers of liberal arts and English. This finding likely indicates a desire on the part of these teachers to apply their math and science knowledge, valued areas of expertise in China's Four Modernizations, to positions in other sectors, with the consequent higher pay, benefits, and status. It was also found that the type of school, keypoint versus ordinary, influenced teachers' views regarding work conditions, with urban keypoint school teachers reporting less job-related stress than suburban ordinary school teachers.

It is not surprising that younger teachers and male teachers are more likely to perceive less satisfaction with the profession of teaching, for it is this same group of teachers that is more likely to have the highly-valued college degrees and, therefore, better preparation than other teachers. To have pay and benefits that are less than those of a modestly educated laborer and much less than college graduates in other occupations, along with a lower status, would, logical1y, result in a higher level of dissatisfaction. 
Questionnaire items related to the hypothesis concerning the examination system and the heavy workload of most secondary school students included the issues of teaching methodology and discipline. It was expected that responses would be influenced by teachers' years of experience and age, with younger teachers expressing more of a need for educational change. As hypothesized, older teachers expressed less sympathy for the heavy academic load of students and reported a stronger need for firmness, consistency, and discipline than did younger teachers. 01der teachers also were more likely to feel that permissive parenting is the cause of behavior problems at school. These beliefs suggest a more traditional, "parental" stance. Younger teachers reported a stronger perception that they make a difference in the lives of the students they teach and, not surprisingly, feel that younger teachers are more capable than older teachers. This latter perception may, again, relate to the higher likelihood that younger teachers hold college degrees and, therefore, have better preparation than older teachers.

The hypothesis related to teacher preparation predicted that most teachers would perceive that they are inadequately prepared to meet the demands of teaching, and that responses would be influenced by gender, years of teaching experience, and years of post-secondary training. While the majority of teachers participating in this study believe that teacher training is insufficient, the above-mentioned variables were not found to be particularly influential. As mentioned earlier, teachers with less experience, i.e., younger, more likely to hold a college degree, and, also more likely to be male, judged themselves to be more 
capable. However, it is not clear that they necessarily feel more adequate in preparation for teaching. An unexpected finding was that teachers of 1 iberal arts subjects (social sciences, music, and Chinese) perceived themselves as significantly better prepared than teachers of other subjects.

Questionnaire items related to the hypothesis regarding the secondary school curriculum and teaching methodology predicted that most teachers believe there is a need for curriculum reform. It was predicted that teachers see the need for more "give and take" in the education system, with more student participation, more emphas is on thinking than on memorizing facts for the examinations, and more variety in courses offered, especially for the non-college bound majority. It was hypothesized that teacher age/years of teaching experience and type of school (keypoint versus ordinary schools) would influence responses. Most teachers participating in this study agreed that teaching students to think should be emphasized over memorizing facts and that the process of learning is more important than the product, i.e. test performance. However, as expected, the key school teachers expressed significantly less agreement with the teaching of thinking skills over memorizing facts, than did ordinary school teachers whose students are unlikely to sit for the university entrance examinations.

Most teachers also agreed that students should be given more freedom to speak their minds in the classroom, with male teachers in strongest agreement. The majority also held the view that college-bound students are favored over other students and that minority students should be given special attention within the education system, 
non-degreed teachers expressing the most agreement with the latter belief. There are many sociological implications for these findings. As China has allowed more open discussion of political issues and seen increasing dissent on the part of university students and intellectuals, particularly males, it is likely that the views of teachers will be influenced and that a more positive attitude toward classroom discussion will follow. Likewise, the "right" of the non-college bound student and the minority student to have an appropriate educaion has been more in the public eye, perhaps influencing teacher attitude toward these poputations.

The majority of teachers participating in this study held the view that the arts should be included in the curriculum. However, sex education was not as widely endorsed. It was found that younger and better educated teachers, as well as the female teachers without degress, felt most strongly about the need for sex education in the school curriculum. 0lder males without degrees were the least likely to see the need, employing instead a more traditional and conservative position.

In short, the hypotheses which guided this study were generally supported by the data gathered. These teachers were found to express their beliefs in a number of areas and reflected the perception of negative social status, poor pay, inadequate working conditions, insufficient teacher preparation, and insufficient government support. They also indicated a need for and support for changes in the secondary school curriculum and teaching methodology.

Although the results of this study contribute to our understanding 
of the positions and experiences of secondary school teaching in China, it is important, at this time, to temper these conclusions with possible limitations. Drawing conclusions about the state of the teaching profession throughout China and the perceptions of secondary teachers in general, based on this sma11, unrepresentative sample is, of course, inappropriate. The small number of teachers participating and the single, urban community represented, place severe limitations on the generalizability of the results.

On the other hand, it is interesting to hypothesize how the results might differ in a rural area where, most likely, there would be fewer teachers with college degrees, fewer keypoint schools/teachers, and, perhaps, a more conservative, traditional population than in the capital city. While it is convenient to think that the views reported here are representative of more liberal, well-prepared, and privileged teachers, it is also important to remember that a capital city generally offers more opportunities for educated people. Drawing conclusions regarding secondary teachers across China is unwarranted. However, results of this study do support previous findings regarding dissatisfaction with the education system and teaching profession. They also provide information regarding the differences between younger and older teachers, those with degrees and those without, and subject area differences. And they do provide continuing evidence of the desire, on the part of many teachers, to take part in defining the educational concerns and engaging in dialogue which may, ultimately, improve the lives of teachers and students, and China's education system, in general. 


\section{RECOMMENDATIONS}

While the foregoing discussion has touched upon certain of the procedural limitations of the study, further discussion will now be directed to the Teacher Questionnaire itself.

Aside from the issues of transiation of questionnaire items (from English to Chinese), which may have resulted in some communication difficulties, and the unfamiliarity, and possible suspicion, on the part of the Chinese with research studies, there is the question of whether the particular 60 items comprising the questionnaire were able to tap the areas of most concern to teachers. Because so little information has been published regarding teacher opinion in China, other than regarding pay and status issues, the development of questionnaire items was considered only an initial attempt at designing an instrument which might provide useful insight regarding China's education system from the perspective of teachers.

One of the secondary goals of this study was to factor analyze the items in the Teacher Questionnaire in an effort to determine specific domains which, as scales. more adequately assess educational belief systems of teachers. Unfortunately, sample size would have to be tripled to successfully and meaningfully complete this exercise. Thus, a goal of any future research should hold as one of its objectives, a sufficient sample population to compute a factor analysis.

Several unanticipated outcomes emerged which may provide future directions for research. First, it was thought that there would be differences between the perceptions of keypoint school teachers and 
ordinary school teachers. As previously discussed, keypoint schools are known to have the best facilities, equipment, and materials, along with the most highly regarded teachers and the most able students. One might assume, then, that teachers at these schools would find their status, working conditions, and stress to be less objectionable than those of ordinary school teachers, and that their satisfaction to be greater. Results of this study reveal few differences of opinion between teachers at the two types of schools. However, keypoint teachers reported significantly stronger views that their school administrators were not helpful or supportive to them in their teaching. In addition, teachers supplying written comments, mentioned the lack of support of administrators, lending credence to this concern. Future research may wish to probe this area, developing questionnaire items, for instance, regarding administrator qualifications and abilities. Identifying characteristics of effective administrators may be useful information if an educational reform movement gains impetus.

Another area of possible further study is that of differences between teachers of various subject areas. The limitation of small sample size, no doubt, played a role in identifying liberal arts teachers as perceiving themselves to be better prepared than teachers of other subjects. However, the general notion that subject area taught may influence teachers' perceptions is reinforced by the differences expressed by science and math teachers, who regard themselves as far less satisfied than teachers of other subjects. It is not known if college preparation has played a role in teacher perception of preparedness. Of, perhaps, more relevance would be an investigation 
into the perception of effectiveness of various inservice programs, since most teachers in China are prepared through these means.

A comparison of the opinions of rural teachers, with those of urban teachers, are likely to result in variations of perception. The appropriateness of the national curriculum to rural students has been questioned, but it is unclear as to what teachers think. The needs of rural communities differ from those of urban communities, with education seen as more important in cities. Do teachers in rural communities perceive the same lack of status as urban teachers and do they express similar views? A comparison of teachers in provincial capitals with teachers in other cities and towns, as well as urban areas, would contribute to an understanding of the national picture of the teaching profession.

This study was limited to secondary teachers. The views of primary teachers would add an important and useful dimension. There are roughty twice as many primary teachers as secondary teachers in China, and their status is considered to be less than that of secondary teachers.

The teachers who participated in this study appeared to be willing to share their perceptions, and, in a number of cases, their frustrations with the current status of the teaching profession and the secondary education system. It is hoped that this investigation will contribute toward the efforts of providing a voice for the teachers of China and encouragement to others who are interested in bettering the working conditions of teachers. 


\section{REFERENCES}

Abelson, A.G. (1986). A factor-analytic study of job satisfaction among special educators. Educational and Psychological Measurement, 46, $37-43$.

Altbach, P. (1987). Teaching: International concerns. Teachers College Record, 88 (3).

Altbach, P. and Kelly, G. (Eds.) (1986). New approaches to comparative education. Chicago: The University of Chicago Press.

Bastid, M. (1984). Chinese educational policies in the 1980 s and economic development. The China Quarterly, 98, 189-219.

Broadfoot, P. and Osborn, T. (1987). Teachers' conceptions of their professional responsibility: Some international concerns. Comparative Education, 23 (3), 287-298.

Brown, H. 0. (1986). Primary schooling and the rural responsibility system in the People's Republic of China. Comparative Education Review, August, 373-387.

Butterfield, Fox (1982). Alive in the bitter sea. New York: Times Books.

Carnoy, M. (1982). Educating for alternative development. Comparative Education Review, 26 (2), 187-199.

Chen, T. H. (1984). Educational development in the People's Republic of China, 1949-1981. In H. Chiu with S. Leng (Eds.), China Seventy Years After the 1911 Hsin-Hai Revolution. Charlottesville: University Press of Virginia.

China Data (1986). Development of education and relevant policies. China Report, October-December, 503-548.

China Handbook - First Edition (1983). Education (Chapter One). Beijing: Foreign Languages Press.

Cleverly, J. (1985). The schooling of China. London: Croon Helm.

Collins, H. (1981). Back to basics in China. American Education, March, 28-31. 
Coombs, P.H. (1985). The world crisis in education - A view from the eighties. New York: Oxford University Press.

Cowen, R. and McLean, M. (Eds.) (1984). International handbook of education systems, Volume III, Asia, Australia, and Latin America. Toronto: John Wiley and Sons.

Dove, L.A. (1986). Teachers and teacher education in develooing countries. Dover, NH: Croom Helm.

Fimian, M.J. (1984). The development of an instrument to measure occupational stress in teachers: The Teacher Stress Inventory. Journal of Occupational Pyschology, 57, 277-293.

Gamberg, R. (1977). Red and Expert: Education in the People's Republic of China. New York: Shocken Books.

Goodlad, J.I. (1984). A place called school - prospects for the future. San Francisco: McGraw-Hill Book Co.

Guo, Zhongshi (1988, February 5). Teachers support pay raise. China Daily, 1 .

Ha11, G. (1974). The CBAM project. R \& D Center for Teacher Education, Austin: University of Texas.

Hawkins, J. (1982). Educational reform and development in the People's Republic of China. In P. Altbach, R. Arnove, \& G. Kelly (Eds.), Comparative Education. New York: MacMillan Publishing Company, Inc.

Hawkins, J. (1983). Chapter 4: The People's Republic of China. In R. M. Thomas and T. N. Postlethwaite (Eds.), Schooling in East Asia. New York: Pergamon Press.

Holmes Group (1986). Tomorrow's teachers: A report of the Holmes Group. East Lansing: The Holmes Group.

Hooper, B.(1985). Youth in China. New York: Penguin Books.

Johnson, M. (1986, November 17). China's classroom crisis. Time, 33.

Kaufman, B. (1964); Up the down staircase. Englewood Cliffs, N.J.: Prentice-Hail, Inc.

Kessen, W. (1976). Childhood in China. New Haven: Yale University Press.

Koht, H. (1967). 36 children. New York: The New American Library, Inc. 
Li Shuxi (1981). Life and work of a primary teacher. China Reconstructs, August, 67-68.

Li Xing (1987, May 22). Teachers take pains to improve rural education. China Daily, 7.

Li Xing (1987, June 30). Education law, year old, faces problems. China Daily, 1.

Li Xing (1988, February 15). Li urges universities to speed job reforms. China Daily, 3.

Lieberman, A. and Miller, L. (1984). Teachers, their world, and their work. Alexandria, VA: Association for Supervision and Curriculum Development.

Lipset, S.M. (1967). The first new nation. Garden Ciy, N.Y.: Doubleday Publishers.

Lo, Billie L. C. (1983). Research quide to education in China after Mao -- 1977-81. Hong Kong: University of Hong Kong (Centre of Asian Studies).

Lo, Billie L. C. (1984). Teacher education in the eighties. In R. Hayhoe (Ed.), Contemporary chinese education. London: Croon Helm.

Lortie, D. (1975). School teacher: A sociological study. Chicago: University of Chicago Press.

Mann, J. (1987). Thousands of students demonstate in China. Oregonian, 4.

Martin, R. (1982). The socialization of children in China and on Taiwan: An analysis of elementary school textbooks. In P. Altbach, R. Arnove, \& G. Kelly (Eds.), Comparative education. New York: MacMillan Publishing Company, Inc.

Mauger, P. (1982). Changing policy in Chinese rural education. China Quarter7y, 85, 138-148.

Morton, W.S. (1980). China, its history and culture. San Francisco: McGraw-Hill Book Co.

National Commission on Excellence in Education (1983). A nation at risk: The imperative for educational reform. Washington, D.C.: U.S. Department of Education.

Pepper, S. (1970). Education and political development in Communist China. Studies in Comparative Communism, $\underline{3}$ July-October, 132-157. 
Rutter, M. (1979). Fifteen thousand hours: Secondary schools and their effects on children. Cambridge: Harvard University Press.

Robinson, J.C. (1986). Decentralization, money, and power: The case of people-run schools in China. Comparative Education Review, 30 (1), 172-179.

Rosen, S. (1981). Obstacles to educational reform in China. Modern China, 8 (1) 3-40.

Shirk, S. (1979). Educational reform and political backlash: Recent changes in Chinese educational policy. Comparative Education Review, 23 (2), 181-187.

Spence, J. D. (1981). The gate of heavenly peace. New York: The Viking Press.

Sylvia, R.D. and Hutchinson, T. (1985). What makes Ms. Johnson teach? A study of teacher motivation. Human Relations, 38 (9), 841-856.

Thøgersen, S. (1987). China's senior middle schools in a social perspective. The China Quarterly, 109, 72-100.

Traver, R. (1987). Essay review of The Handbook of Research on Teaching, M.C. Whittrock (Ed.). Teachers College Record, 88 (33), 443-452.

UNESCO (1980). UNESCO statistical yearbook. Paris: UNESCO.

Unger, J. (1982). Education under Mao. New York: Columbia University Press.

White, G. (1981). Party and professionals - the political role of teachers in contemporary China. Armonk, NY: M. E. Sharpe, Inc.

White, T. K. (1983, September 26). China: Burnout of a revolution. Time, 30-49.

Whittrock, M.C. (Ed.) (1986). The handbook of research on teaching, 3rd Edition. New York: Macmillan PubTishing Co.

World Bank (1980). Education sector policy paper. Washington, D.C.: World Bank.

Wu, Yen-bo (1988). To teach or not to teach, that is a question. (Unpublished manuscript).

Xiao, Sun (1986, November 27). Diploma, skill not synonymous. China Daily, 4. 
Zachariah, M. (1985). Lumps of clay and growing plants: Dominate metaphors of the role of education in the third world, 1950-1980. Comparative Education Review, 29 (1), 462-474.

Zhang, Lin (1986, September 25). Teacher shortage is a pressing problem. China Daily, 4. 
APPENDIX A

TEACHER QUESTIONNIARE

Sex

Age

Years of Education

Highest Educational Degree

Name of school/college/ university attended
Number of years of teaching

(including current year)

Subjects(s) currentiy teaching

Type of school (ordinary or key)

In this Questionnaire you will find a list of statements concerning education. For each statement, please indicate how accurately (to what degree) it describes your point of view. The accuracy with which a statement describes your point of view is indicated by using the following scale:

1

2

3

4

5

6

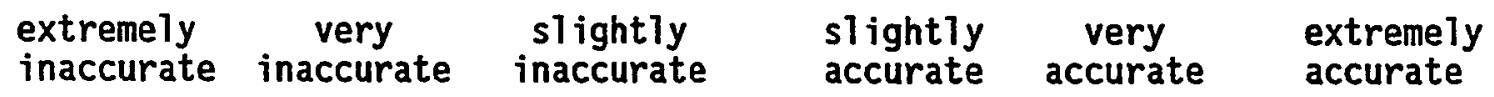

Take the following statement, for example: "I find teaching (the work of teachers challenging." How accurately does this statement describe your point of view? If you think it is a "very accurate" description of your viewpoint, then please write the number " 5 " to the left of the statement, like this:

5 I find teaching (the work of teachers) challenging.

If, however, you think that the statement is a "slightly inaccurate" description of your viewpoint, then please write the number " 3 " to the left of the statement. Similarly, if it is very inaccurate, then please write the number "2," etc. 
TEACHER QUESTIONNAIRE (continued)

1. It is not important to me what my students think of me, just so they learn the material.

2. Women are generally better teachers than men.

3. My closest friends are also teachers.

4. The pay I receive is fair for my level of education and training.

5. The status of teachers will be better in the future.

6. I feel that I control the events in my life.

7. There is adequate time for me to $\mathrm{plan}$ and organize my daily teaching.

8. It is the student's responsibility to learn, regardless of the teacher's skill level.

9. Parents, more than teachers, should be responsible for teaching their children about moral values.

10. My schoor administrator is very supportive and helpful to me in my teaching.

11. The vacations and holiday time for teachers are important benefits of the profession.

12. I feel that I have good social status as a teacher.

13. People should work for the common good of the society (not just for themselves).

14. There are adequate resources at my school to assist me in my teaching.

15. I am concerned about how my teaching will affect my students' lives.

16. My knowledge about teaching methods is 1 imited.

17. I feel the national government is supportive of education.

18. Students should be allowed to speak their minds in the classroom.

19. I feel wel1-prepared for teaching.

20. I feel that a course in sex education should be taught to students in middle schools.

21. If the pay was higher I would be more satisfied being a teacher.

22. I experience much stress in my teaching profession. 


\section{TEACHER QUESTIONNAIRE (continued)}

23. There are good opportunities for promotion in the field of education.

24. My family is proud of me being a teacher.

25. Tenure, or having a job until retirement, protects incompetent teachers (i.e. is a bad system).

26. As a teacher I can make a difference in a student's life.

27. The primary reason for behavior problems in the classroom in from permissive parenting at home.

28. Real learning occurs more from life experiences than from books.

29. Observing other teachers has been helpful to my teaching.

30. I am dissatisfied being a teacher.

31. Teachers in my past have positively influenced me.

32. Part of a teacher's responsibility is to influence school policy regarding organization and operation.

33. I find the field of teaching to be challenging.

34. My supervisor does not give me adequate feedback about my teaching.

35. Teachers must be responsible for being good role models for their students.

36. Individuals preparing to teach should meet high educational standards.

37. I feel committed to teaching.

38. I feel I have the independence to choose which teaching methods I will use in my classroom.

39. The requirements for becoming a teacher should not be so strict.

40. Since becoming a teacher I feel my health is poorer.

41. I am interested in helping students learn.

42. My school has a good reputation for the quality of its students.

43. Teachers should take an active role in disciplining students.

44. Student interaction inhibits learning. 
TEACHER QUESTIONNIARE (continued)

45. My school has a good reputation for the quality of its teachers.

46. It is more important to teach students how to think rather than just to Tearn facts.

47. Being firm and consistent with students is critical in teaching.

48. I enjoy working with young people.

49. The process of learning is more important than the product of what is learned.

50. Minority students should be given special attention to assure them a proper education.

51. A teacher should have the right to use physical punishment with students.

52. The government at the national level should be less involved in education.

53. Schools generally tend to favor the college-bound student rather than the students who will work after leaving high school.

54. Younger teachers are generally more capable than older teachers.

55. The arts (music, painting, drama, etc.) should be included in the school curriculum.

56. I feel envious when I see other teachers transfer to non-educational institutes.

57. There are not adequate courses available in education, psychology, and teaching methodology in our teachers' colleges.

58. I believe that tests heip encourage students to study more.

59. Students would enjoy their studies more without tests.

60. Students are so heavily loaded with their studies that they do not have enough opportunity to develop their own personalities. 
APPENDIX B

TEACHER QUESTIONNAIRE (CHINESE)

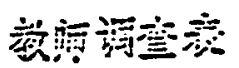

鉴剥

所警学棕

羊然

瓷分

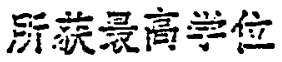

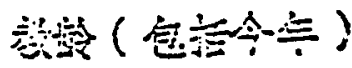

城区/奶/农村

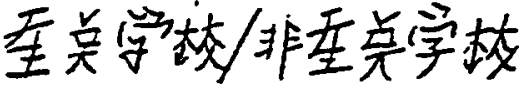

柴旦六兴 / 学睆

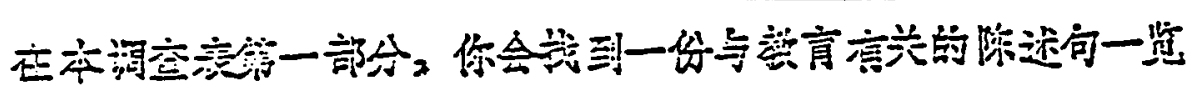

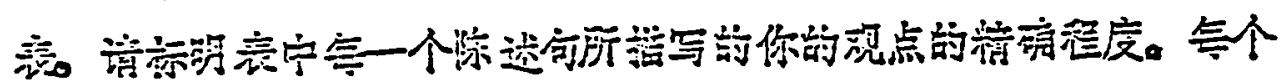

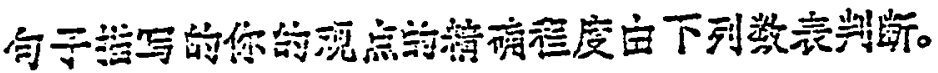
1
2
3
4
5
6

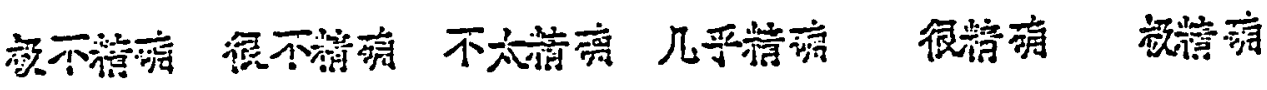

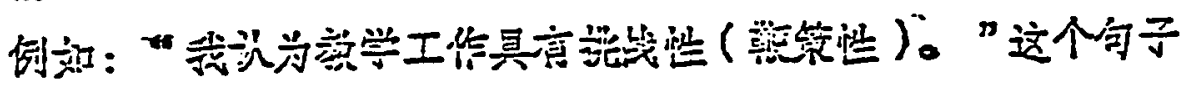

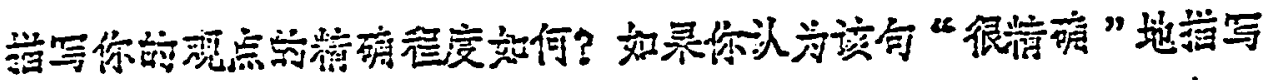

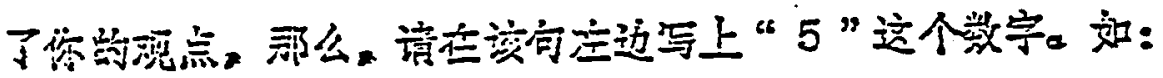

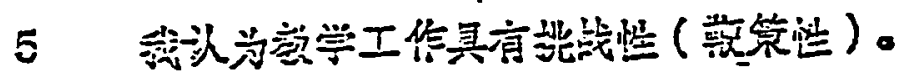

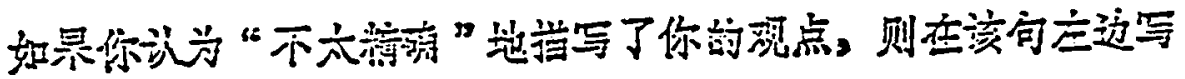

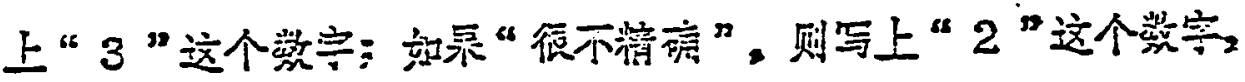
综此类蒋。 
TEACHER QUESTIONNAIRE (continued)

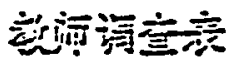

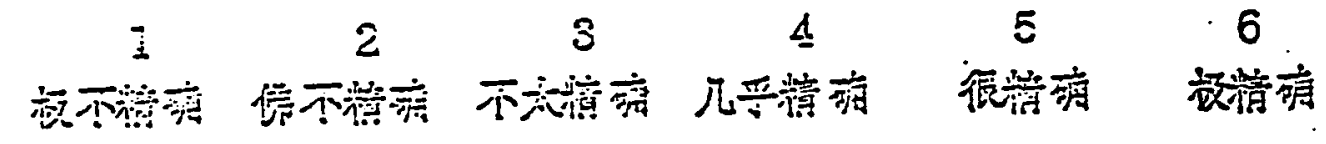

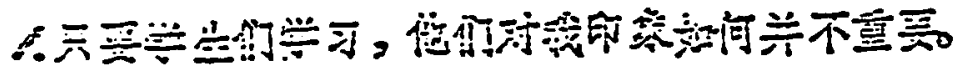

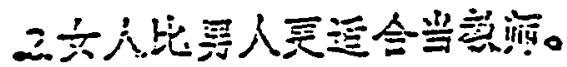

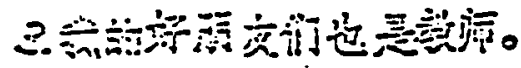

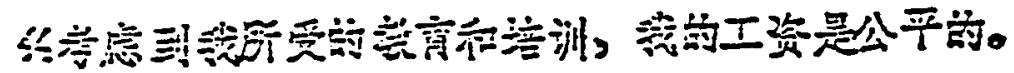

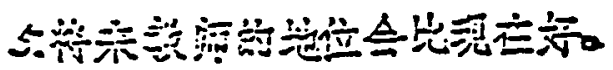

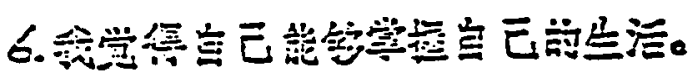

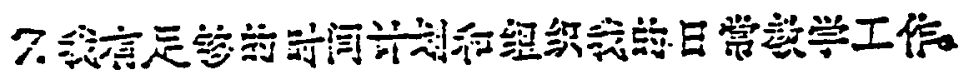

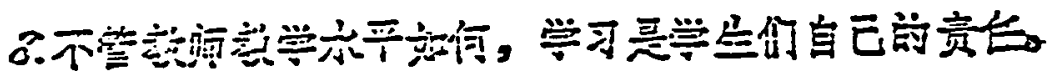

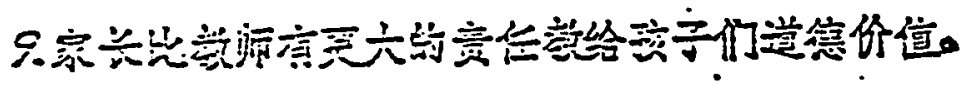

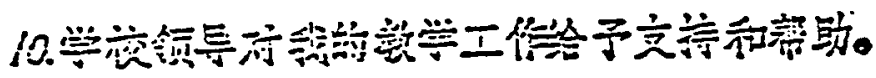

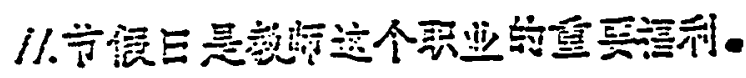

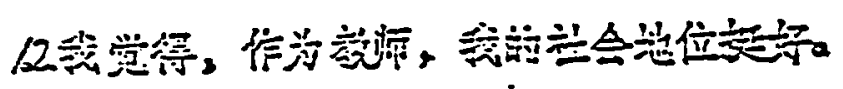

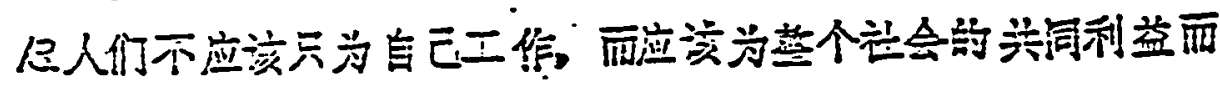
工悲

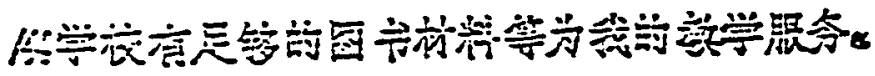

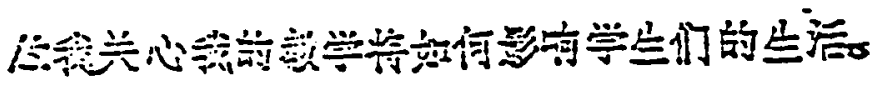

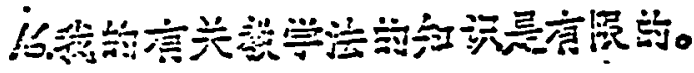

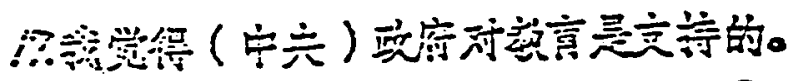

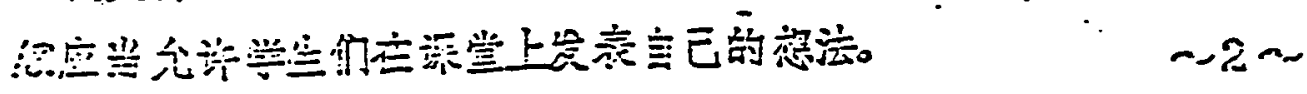


TEACHER QUESTIONNAIRE (continued)

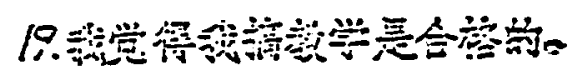

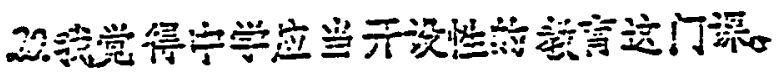

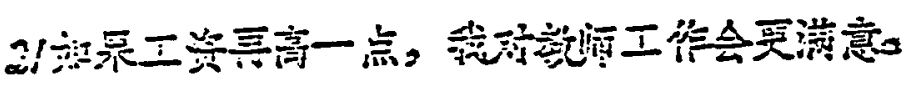

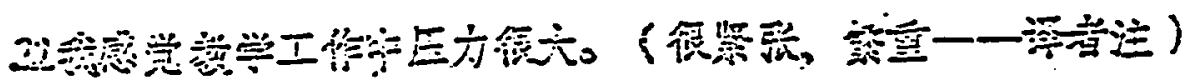

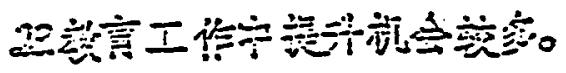

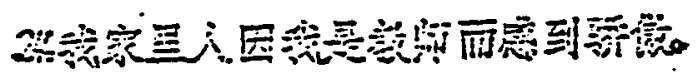

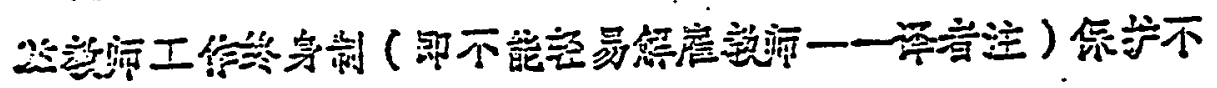

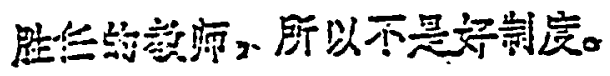

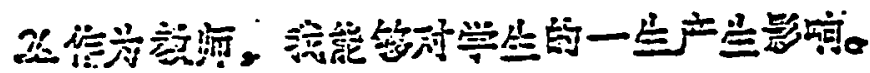

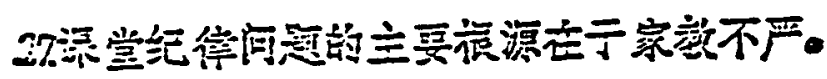

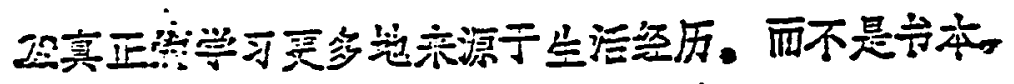

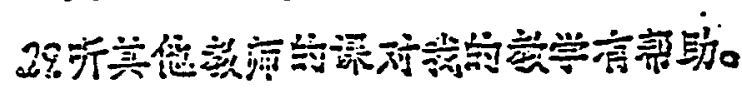

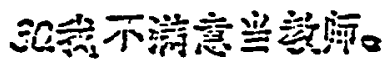

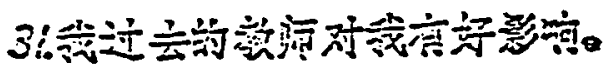

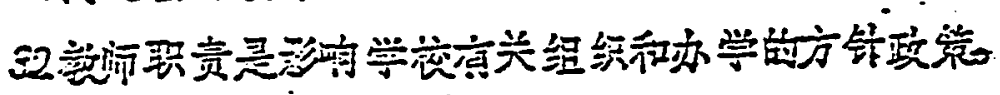

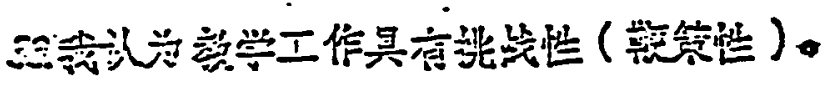

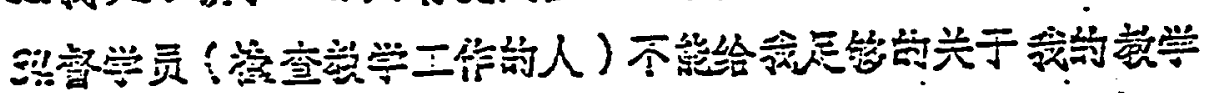
工垈视反管。

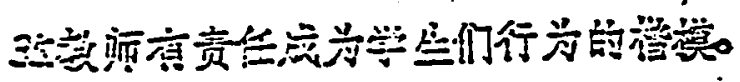

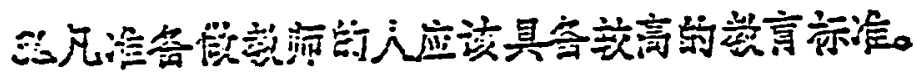

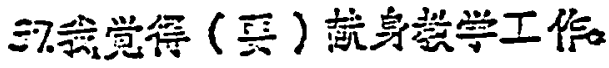

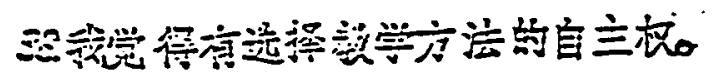

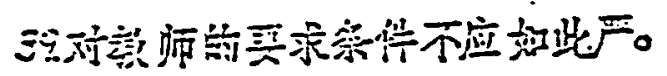


TEACHER QUESTIONNAIRE (continued)

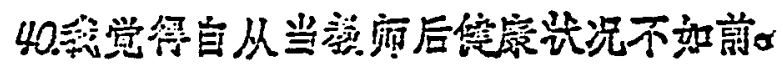

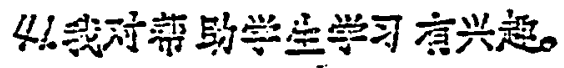

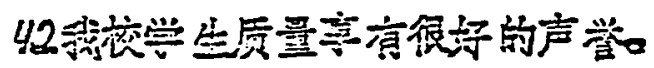

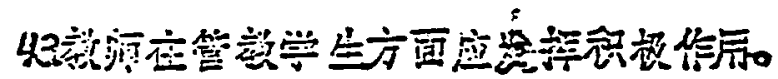

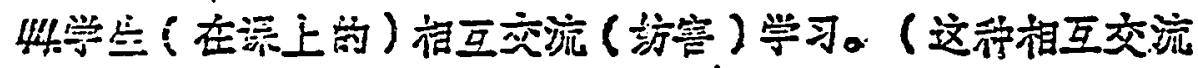

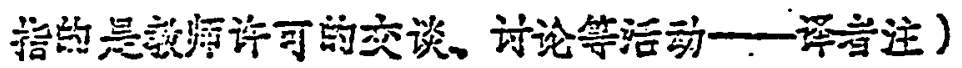

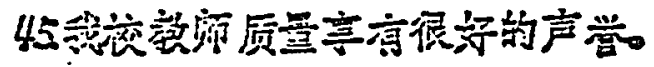

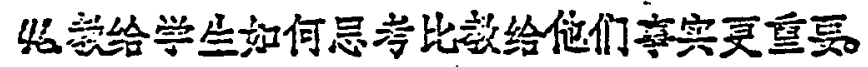

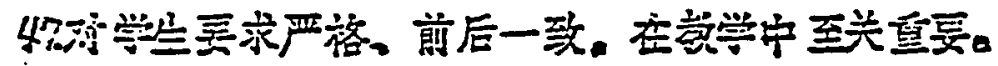

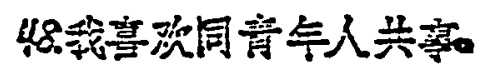

49.学习过定比学习成界要重要。

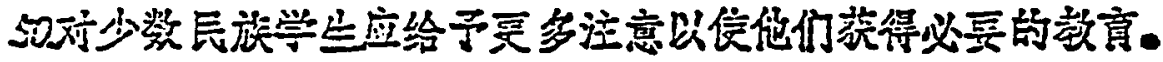

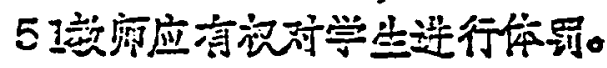

52 (宁共) 形府对产育不应过多介入。

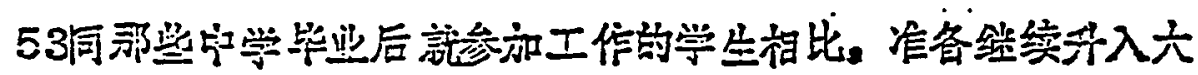
学约学全通常受到学密偏爱。

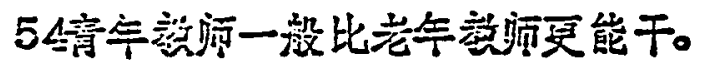

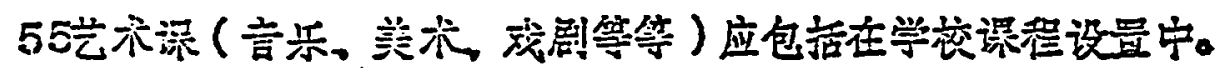

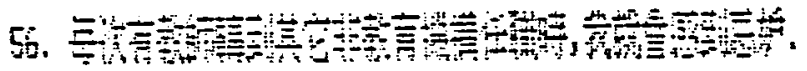

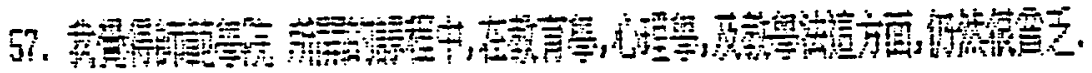

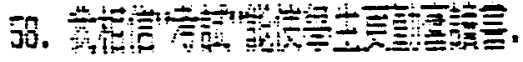

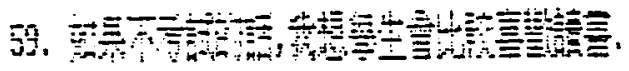

9. 


\section{APPENDIX C}

LETTER TO PARTICIPANTS (ENGLISH)

\section{Dear Teacher:}

You have been selected to participate in a research study which is investigating the opinions and attitudes of teachers. This study does not require that you give your name. In fact, we do not wish to know your name. We would like you to feel free to give your honest opinions.

This is an important study and we would like you to complete the form to the best of your ability. If you have comments regarding your teacher preparation, your teaching position, or your feel ings about the field of education, please write them on an additional piece of paper.

When you have completed the form, please place it in the stamped envelope provided and mail it. We are hoping that the results of this study can be used to better understand the views of teachers and, ultimately, lead to improvements in the field of education. Your participation is greatly appreciated. Thank you.

Sincerely,

Li Wei

Instructor, Department of Engl ish

Beijing Teachers College 
APPENDIX D

LETTER TO PARTICIPANTS (CHINESE)

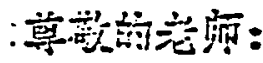

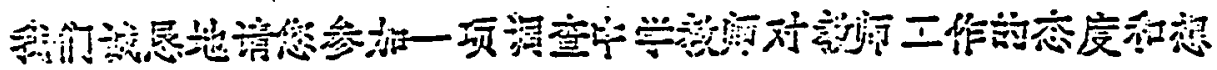

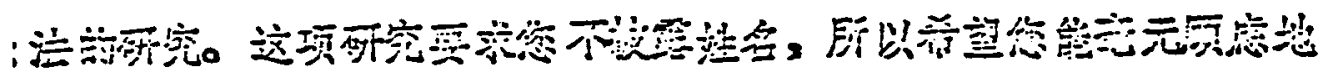

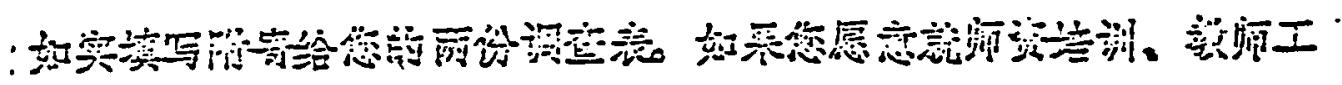

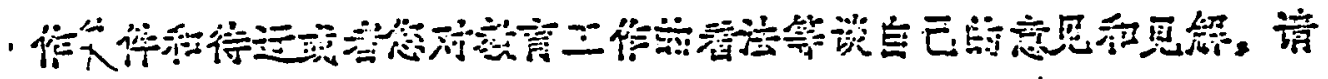

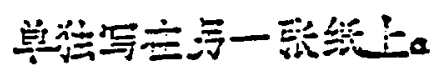

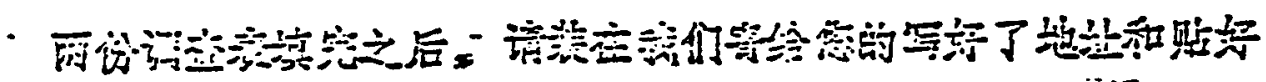

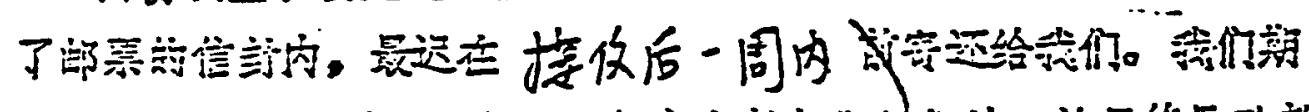

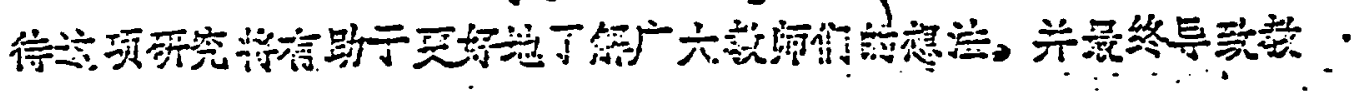

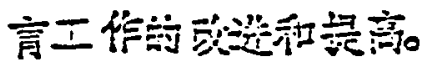

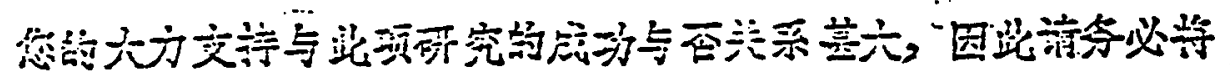

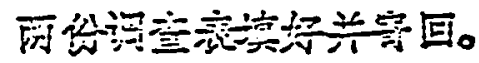

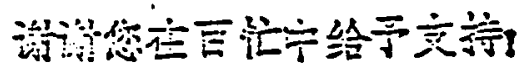
部琴

乫 礼

联系人，北京旅范学馆注要系 望 祒

一完八六年 $f=\beta=+10 \theta$ 


\section{APPENDIX E}

\section{GLOSSARY}

\section{CCP: Chinese Communist Party}

danwei: system of Chinese Communist Party control whereby each Chinese citizen belongs to a factory, school, office, or neighborhood group whose leaders assign jobs, apartments, and travel permits, decide when marriages and births may take place, and, in general, control the lives of people in the group.

keypoint schools (zhongdian): a group of "model" primary and secondary schools and colleges and universities which recieve the bulk of government funding for education, these schools have the best qualified teachers, the best facilities and equipment, and the brightest students. Located in urban areas, keypoints (or key schools) themselves are ranked, with national key schools receiving more funding than provincial key schools, which in turn receive more than municipal, etc. Teachers in key schools have better housing and benefits than those in ordinary schools.

middle schools: comparable to junior and senior high grades in the U.S., middle schools are divided into lower (or junior) and upper (or senior). They are also referred to as secondary schools.

minban schools (minban xuexiao): translated "people-run schools," these lowest status, lowest quality schools are funded at the local level but controlled and guided by provincial and central education experts. Minban schools were originally formed in order to promote local interests and allow peasants a voice in the school curriculum and in teacher hiring. Due to conflicts between peasants and teachers regarding salaries, work hours, qualifications, accountability, etc., local autonomy is being replaced by provincial and national controls. Most minban teachers lack teacher training and may not have completed senior, or even junior, secondary schooling.

normal secondary schools: senior secondary schools with a two, three, or four year curriculum aimed at training students to become primary teachers. 
GLOSSARY (Continued)

"ordinary" schools: also known as "regular" schools, these government-funded primary and secondary schools are administered by provinces, counties, municipalities, and districts, and alloted only a tiny fraction of what the keypoint schools receive. Teachers are less qualified and the facilities are poor. While the curriculum is about the same as that of the key schools (i.e., academic, college-preparatory), most students have virtually no chance of passing the unversity entrance exam due to the poor quality of instruction. Behavior problems and dropouts are rampant at the secondary levels as students realize their educations will not prepare them for jobs or higher education.

putonghua: "Mandarin" or northern dialect adopted as the national language of China; the language of instruction in the schools.

Young Pioneers: the Chinese Communist Party organization for primary students. The Communist Youth League is the organization for adolescents. 